Quantifying the competing influences of lithology and throw rate on bedrock river incision.

\title{
Kent, E
}

http://hdl.handle.net/10026.1/16434

\subsection{0/B35783.1}

Bulletin of the Geological Society of America

Geological Society of America

All content in PEARL is protected by copyright law. Author manuscripts are made available in accordance with publisher policies. Please cite only the published version using the details provided on the item record or document. In the absence of an open licence (e.g. Creative Commons), permissions for further reuse of content should be sought from the publisher or author. 


\section{Quantifying the competing influences of lithology and throw rate on bedrock} river incision.

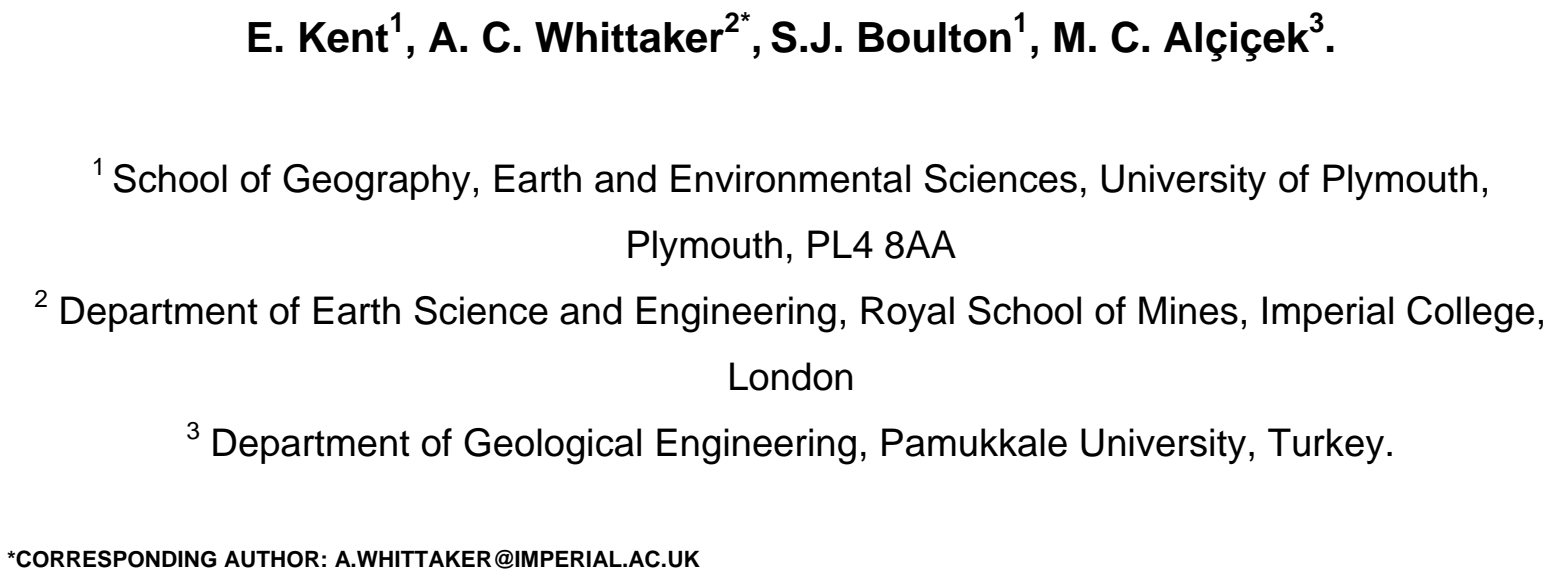

\section{ABSTRACT (MAX 250 WORDS)}

River incision in upland areas is controlled by prevailing climatic and tectonic regimes, which are increasingly well-described, and the nature of the bedrock lithology that is still poorly constrained. Here, we calculate downstream variations in stream power and bedrock strength for six rivers crossing a normal fault in Western Turkey, to derive new constraints on bedrock erodibility as function of rock type. These rivers are selected as they exhibit knickzones representing a transient response to an increase in throw rate, driven by fault linkage. Field measures of rock mass strength show that the metamorphic units (gneisses and schists) in the catchments are $\sim 2$ times harder than the sedimentary lithologies. Stream power increases downstream in all rivers, reaching a maxima upstream of the fault within the metamorphic bedrock but declining markedly where softer sedimentary rocks are encountered. We demonstrate a positive correlation between throw rate and stream power in the metamorphic rocks, characteristic of rivers obeying a detachmentlimited model of erosion. We estimate bedrock erodibility in the metamorphic rocks as $k_{b}=2.2-6.3 \times 10^{-14} \mathrm{~ms}^{2} \mathrm{~kg}^{-1}$; in contrast, bedrock erodibility values are $5-30$ times larger in the sedimentary units with $k_{b}=1.2-15 \times 10^{-13} \mathrm{~ms}^{2} \mathrm{~kg}^{-1}$. However, in the sedimentary units stream power does not scale predictably with fault throw rate, and we evaluate the extent to which the friable nature of the outcropping clastic bedrock alters the long term erosional dynamics of the rivers. This study places new constraints on bedrock erodibilities upstream of active faults and demonstrates that the strength and characteristics of underlying bedrock exert a fundamental influence on river behaviour. 
KEYWORDS: stream power, rivers, erosion rate, knickzone, Gediz Graben

\section{INTRODUCTION}

One of the most significant ways in which tectonic and climatic forcing drives landscape evolution is through the action of rivers at the Earth's surface (Lave and Avouac, 2001; Wobus et al., 2006; Kirby and Whipple, 2012; Whittaker et al., 2012; Ferrier et al., 2013; D'Arcy and Whittaker, 2014). Consequently, in the past two decades landscape evolution models (LEMs) have been widely developed to quantify the impact of external factors, such as active faulting, upon bedrock rivers and the surrounding landscape (Braun and Sambridge, 1997; Tucker et al., 2001; Hancock et al., 2002; Whipple and Tucker, 2002; Willgoose, 2005; Van De Wiel et al., 2007; Perron and Fagherazzi, 2012). Owing to the importance of rivers in driving erosion in these models, it is vital that time-integrated fluvial incision is appropriately parameterised (e.g. Tucker and Whipple, 2002; Lague et al., 2014). It is also necessary to constrain how factors such as channel slope, geometry and discharge may control shear stresses on the bed, and thus modulate bedrock erosion over time and space (Lavé and Avouac 2001; Duvall et al. 2004; Whittaker et al., 2007b, Whittaker et al., 2008; Allan et al., 2012; Whittaker and Boulton, 2012). Stream power erosion laws, which relate the rate of bedrock incision, $E$, to local channel slope, $S$, water discharge, $Q$, (or upstream drainage area, $A$, as a proxy) have been commonly used for this purpose as they are relatively tractable for both modelling and for applications over longer timescales (e.g. Kirby and Whipple, 2012; Lague et al., 2014).

In general, the family of stream power erosion laws can be expressed for rivers near the detachment-limited end-member as

$$
E=K A^{m} S^{n}
$$

where exponents $m$ and $n$ can be determined empirically or theoretically, and $K$ is a coefficient which encapsulates, alongside additional variables, bedrock erodibility (Whipple and Tucker, 1999; Tucker and Whipple, 2002). The value of $K$ (and the units in which it is expressed) depends on the choice of stream power model. While equation 1 (and variants thereof) is routinely employed in numerical modeling or topographic analyses (e.g. Wobus et al., 2006; Schwanghart and Scherler, 2014; 
Clubb et al., 2019), where field data allow, a unit (or specific) stream power model (c.f. Whittaker et al., 2007a; Attal et al., 2008; Zondervan et al., 2020a) can be used. In this case,

$E=k_{b} \omega=k_{b} \frac{\rho \mathrm{gQS}}{W}$

where the unit stream power, $\omega$ represents energy dissipation per unit channel area on the bed with units of $\mathrm{Wm}^{-2}, \rho$ is the density of water, $g$ is the acceleration due to gravity, $Q$ is the water discharge $\left(\mathrm{m}^{3} \mathrm{~s}^{-1}\right), S$ is local channel slope $(\mathrm{m} / \mathrm{m})$ and $W$ the channel width $(m)$. Consequently, it follows that specific bedrock erodibility, $k_{b}$, has units of $\mathrm{m} \mathrm{s}^{2} \mathrm{~kg}^{-1}$, representing the inverse of stress (c.f. Yanites et al., 2017). Whilst the influence of factors such as planform width (e.g., Montgomery and Gran, 2001; Finnegan et al., 2005; Whittaker et al., 2007b; Turowski et al., 2009), channel steepness (e.g., Whipple and Tucker, 2002; Whipple, 2004; Whittaker et al., 2007a), and sediment supply effects (e.g., Sklar and Dietrich, 2001; Finnegan et al., 2007; Cowie et al., 2008) on stream power erosion laws have been widely investigated, the role of bedrock lithology and erodibility in modulating landscape response to base level change remains poorly understood (Stock and Montgomery, 1999; Reneau, 2000; Van der Beek and Bishop, 2003; Brocard and Van der Beek, 2006; Allen et al., 2012; Bursztyn et al., 2015). Unlike other parameters in a stream power model, bedrock erodibility cannot be directly measured from lithological maps or rock strength tests, nor is there agreement about what measure or measures of rock strength are most suited to capture variations in time-integrated substrate erodibility (c.f. Sklar and Dietrich, 2004; Bursztyn et al., 2015). However, for bedrock rivers whose erosional dynamics can be approximated by a specific stream power model, $k_{b}$ can be calculated if and where incision rates are known and where the downsystem distribution of stream power can be computed from field data (Stock and Montgomery, 1999; Attal et al., 2008, Zondervan et al., 2020a).

Lithology has long been identified by researchers as being of potential significance in controlling river behaviour (Howard et al., 1994; Goldrick and Bishop, 1995; Cook et al., 2009; Allen et al., 2013; Ferrier et al., 2013; Croissant and Braun, 2014). Recent landscape evolution modelling demonstrates that variations in bedrock erodibility may play an important role in determining the speed and coherence of knickpoint signals driven by base level change (e.g. Forte et al., 2016; Roy et al., 
2016; Yanites et al., 2017), and when combined with dipping bedrock, complex interactions between fluvial erosion rate and topographic evolution can developed (Forte et al., 2016, Perne et al., 2016). These effects are particularly enhanced where modelled bedrock erodibilities vary by several orders of magnitude. However, there are few field data sets that show these effects unequivocally (c.f. Whittaker and Boulton, 2012; Kent et al., 2017), and few constraints on what bedrock erodibilities would actually be appropriate to characterise the range of rock types encountered in real-world catchments. For instance, Stock and Montgomery (1999) calibrated Equation 1 using geologically-constrained forward modelling of river profiles in a number of localities world-wide and obtained $K$ values that varied by at least 5 orders of magnitude $\left(10^{-7}-10^{-2} \mathrm{~m}^{0.2} \mathrm{yr}^{-1}\right)$ for $\mathrm{m}=0.4$. Kirby and Whipple (2001) and Whipple et al. (2000) also obtained K values for rivers in Alaska and the Siwalik hills of ca. $10^{-4} \mathrm{~m}^{0.2} \mathrm{yr}^{-1}$ although these values embed significant differences in discharge and vegetation between the respective landscapes. In contrast, erodibility values of the order of $1.5-4 \times 10^{-6} \mathrm{~m}^{0.2} \mathrm{yr}^{-1}$ have recently been estimated for the Gulf of Corinth (Pechlivanidou et al., 2018). Significantly, none of the above studies linked these estimates to any physical measurements of bedrock strength or local measurements of channel hydraulic geometry.

In fact, the limited number of field-related studies that have specifically focussed on the role of the bedrock lithology in landscape evolution have generally been undertaken in post-orogenic or tectonically quiescent regions with low or negligible rates of tectonic uplift. For example, Bursztyn et al. (2015) argued that lithological strength is a first-order control on the fluvial geomorphology of the Colorado Plateau using a combination of in situ strength tests and lab tensile testing. Strong positive correlations between rock strength and unit stream power, as well as between rock strength and river slope / width were found in bedrock reaches of the river. Similarly, rock strength as measured by Schmidt Hammer was shown to strongly correlate with river steepness across the Pyrenean (Bernard et al., 2019) and High Atlas (Zondervan et al., 2020b) mountain ranges. Recently, Yanites et al. (2017) argued that lithology played an important role in the post orogenic evolution of the Jura mountains in the Swiss Alps, although mapped rock type and tectonic evolution provided the context for a range of model results rather than as a fully independent data set. 
136 Consequently, field studies are lacking in tectonically-active areas where lithology and uplift rates differ but are independently well-constrained. In principle, for a bedrock river incising to keep pace with known fault uplift with differing footwall lithologies, Equation 2 suggests stream power should scale with the fault slip rate, but should also be predictably modulated by bedrock erodibility (c.f. Cowie et al., 2008; Attal et al., 2008). That stream power scales to fault slip rates has been demonstrated for one set of active faults in the Central Italian Apennines (e.g. Whittaker et al., 2007a; Whittaker et al., 2007b), using field observations. However, the hypothesis that stream power scales with bedrock erodibility in these settings has not (c.f. Kent et al., 2017). Moreover, if measures of rock mass strength were known independently in such a situation, it would enable variations in physical measures of rock properties to be linked explicitly to estimates of bedrock erodibility, $k_{b}$, from Equation 2 (c.f. Burztyn et al., 2015; Zondervan et al., 2020a,b). Finally, where bedrock incision rates do not scale predictably with throw rates, or with measures of bedrock strength, a deduction may be also made about the role of sediment in modulating bedrock incision, as Cowie et al. (2008) demonstrate for catchments draining across active faults bordering the Gulf of Evia, Greece.

In this contribution we address these challenges. We exploit an exceptional field site on the southern margin of the actively-extending Gediz Graben of Turkey, where tectonic and lithological boundary conditions can be constrained independently to: (i) quantify the relationship between stream power and fault uplift rates where rivers cross active faults; (ii) quantify the relationship between stream power, lithology and rock mass strength; (iii) derive the magnitudes of bedrock erodibility for the metamorphic and clastic sedimentary units outcropping in the region. Finally, we explore the extent to which bedrock lithology can influence the erosional dynamics of incision upstream of an active fault.

\section{STUDY AREA}

The Gediz Graben (Figure 1) can be used as a natural laboratory to study the fluvial response of the landscape to active faulting, as the geologic context and tectonic evolution of the area are well-understood and constrained (i.e., Seyitoğlu and Scott, 
1996; Seyitoğlu et al., 2002; Bozkurt, 2003; Bozkurt and Sözbilir, 2004; Çiftçi and Bozkurt, 2009a; Oner and Dilek, 2011; Kent et al. 2016; 2017). In particular, the northward-draining range-transverse rivers have been previously documented to be responding transiently to a documented change in tectonic boundary conditions at $0.8 \pm 0.2 \mathrm{Ma}$ (Kent et al., 2016; 2017).

The Gediz (also known as the Alaşehir) Graben is located in western Anatolia (Figure 1), which has been experiencing N-S extension since early Miocene times, probably as the result of roll-back on the Hellenic subduction zone (Okay and Satir, 2000; ten Veen et al., 2009). The tectonic history of the southern margin of Gediz Graben can be divided into two main phases (Bozkurt and Sözbilir, 2004). Initial extension caused the uplift of the Menderes Massif metamorphic core complex, along the now-inactive low-angle north-dipping Gediz detachment fault (Gessner et al., 2001; Seyitoğlu et al., 2002; Ring et al., 2003). In the footwall of this fault is the Menderes Massif metamorphic core complex composed of greenschist to amphibolite-facies schists, augengneisses, paragneisses, small amounts of marble and phyllite, and small syn-tectonic granodiorites (Gessner et al., 2001; Ring et al., 2003). The majority of the Menderes Massif lithologies exhibit features associated with early ductile deformation such as schistosity and low-angle foliations (Hetzel et al., 1995). These are overprinted by later fabrics such as mineral lineations (with top to the NE sense of shear), cataclasites and mylonites (Hetzel et al., 1995). Faultbound slivers of high-grade gneisses show less internal structure and are thought to have been thrust-emplaced upon low-grade lithologies in an earlier phase of deformation (Hetzel et al., 1995). Intense shearing, mylonites and cataclasites are observed for 20-50 m (Hetzel et al., (1995) below the detachment surface, which is a regionally extensive, corrugated surface dipping $\sim 20^{\circ}$ northwards (Purvis and Robertson, 2005).

Following the cessation of slip on the detachment at ca. $2 \mathrm{Ma}$ (Buscher et al., 2013), strain stepped basinwards (i.e., northwards) onto high-angle faults, including the presently active normal fault forming the southern margin of the present topographic graben (Figure 1). The Gediz Graben boundary fault has a record of historical and recent earthquakes. In $17 \mathrm{AD}$ the Lydia earthquake caused extensive damage to the 
region and to the city of Sardis, capital of the ancient kingdom of Lydia and close to the modern town of Sart (Ambraseys, 2009). More recently, a large magnitude earthquake occurred in 1969 ( $\mathrm{Ms}=6.5$ ), resulting in a surface rupture $>30 \mathrm{~km}$ in length with up to $20 \mathrm{~cm}$ surface displacement along the eastern section of the high angle boundary fault (Arpat \& Bingol, 1969; Eyidoğan \& Jackson, 1985).

In the uplifted footwall of this active fault are friable sedimentary rocks, deposited originally in the hangingwall of the Gediz detachment during the early Miocene to Pleistocene. These sedimentary units unconformably overly the metamorphic basement and are comprised of a complex sequence of variably cemented and laterally discontinuous sandstones and conglomerates deposited mainly in alluvial fan and fluvial environments on the edge of the graben (Purvis and Robertson, 2004; 2005; Çiftçi and Bozkurt, 2009b). Furthermore, mudstones, siltstones, marls and limestones are locally present associated with lacustrine conditions in depocentres or overbank deposition (Çiftçi and Bozkurt, 2009b). These predominantly clastic sediments have numerous sedimentary structures and bed thicknesses that vary from decimeters to $>10$ metres (Çiftçi and Bozkurt, 2009b). It should also be noted that the sedimentary cover to the detachment is cut by numerous small high-angle normal faults, synthetic and antithetic to the boundary fault, which are observed displacing the older detachment surface (Purvis and Robertson, 2005).

The Bozdağ Range, the southern bounding range of the Gediz Graben, has a characteristic topographic asymmetry. The range is steeper on the southern side, with the drainage divide in places offset towards the Küçük Menderes Graben. To the south of the drainage divide, the range slopes steeply into the Küçük Menderes Graben, giving the Bozdağ Range the topographic characteristics of a horst uplift (Figure 1B) with inferred uniform uplift across the tectonic block. Although faults in the Küçük Menderes Graben are not well mapped nor the activity upon them constrained, catchment averaged erosion rates derived from cosmogenic ${ }^{10} \mathrm{Be}$ measurements in southward draining rivers are generally comparable to those draining northwards (Heineke et al., 2019) supporting this supposition. Transverse bedrock rivers flowing northwards into the Gediz Graben are generally deeply incised with prominent knickpoints and gorges upstream of the active fault (Figures 2 and 3). These tectonic knickpoints are not coincident with lithological boundaries or 
the detachment surface and have characteristic morphologies of slope-break knickpoints (Kent et al., 2017). The knickpoints mark the upstream extent of a transient wave of river incision, caused by an increase in slip on the graben bounding fault as a result of fault linkage $0.6-1 \mathrm{Ma}$, as explored in detail by Kent et al. $(2016,2017)$, who integrated structural, tectonic and geomorphic data sets to evaluate the fault slip histories and associated landscape response. As a result of this linkage present day throw rates (the vertical component of the slip rate) are now higher than the long-term geological average, with rates of up to $2 \mathrm{mmyr}^{-1}$ calculated at the centre of the fault array (Kent et al., 2017).

Kent et al. (2017) documented the transient fluvial characteristics of, and calculated the knickpoint retreat rate, knickpoint celerity and post-linkage slip rate at the range front for 29 rivers crossing the fault array. Here, six of these rivers are selected to investigate the lithological and tectonic controls on transient river behaviour (Figure 1). The rivers represent a variety of boundary conditions in terms of the throw rate on the fault and bedrock lithologies (Figure 2 and 3). The highest throw rates are found in the middle section of the basin bounding fault, $\sim 60 \mathrm{~km}$ along strike, while the lowest throw rates are found towards the fault array tips (Kent et al., 2017). The rivers cross the fault in different locations and therefore, are affected by a three-fold spread of quantified post-linkage throw rates, ranging from $0.7-2$ mmyr $^{-1}$ (Figure 1; Table 1).

A range of lithologies are also exposed along the six river channels (Figures 1 - 3), including gneisses and schists of the Menderes metamorphic complex outlined above (Çiftçi and Bozkurt, 2009b; Oner and Dilek 2011), and the Neogene to recent conglomerates and sandstones found in the hangingwall of the inactive Gediz detachment (Purvis and Robertson, 2004; 2005; Çiftçi and Bozkurt, 2009b). The proportion of these lithologies varies between the channels: for instance, the Akçapınar River (Figure 3A) incises only through the metamorphic basement rocks upstream of the fault, while all five of the remaining rivers incise through varying amounts of clastic sedimentary units in the footwall of the active fault in addition to the metamorphic basement upstream of the inactive detachment fault (Figure 3C). The Yeniköy represents the opposite end member with around half the length of the river being underlain by the uplifted clastic sedimentary rocks. These two broad 
groupings of rock types, metamorphic and sedimentary, have been used for the subsequent quantitative analyses given that our qualitative field observations suggested the differences between these two main lithological groups are clearly and consistently observed in the resultant morphology of the six rivers. Finally, it should be noted that the climate of the Bozdağ Range is generally uniform within the study area, with precipitation rates varying from 500 to $1000 \mathrm{~mm} / \mathrm{yr}$ in the highest parts of the range (Şensoy et al., 2008).

\section{METHODS}

\subsection{Field Measurements}

We traversed the six selected rivers in the field from their headwaters in the Bozdağ Range to the range-bounding fault. Detailed channel measurements (supplemental data tables S1 to S6) were taken every 200 - 500 m downstream; study locations were mapped using a hand-held GPS with a spatial precision of $\pm 5 \mathrm{~m}$. In the field we measured bankfull channel width $(W)$; maximum channel depth $(H)$ and local channel slope (S). Hydraulic geometries were measured using a TruPulse laser rangefinder with a precision of $<5 \mathrm{~cm}$. The channel width and height were measured at bankfull stage (Leopold and Maddock, 1953; Knighton, 1998), estimated from features such as the limits of active abrasion, vegetation boundaries, the highest levels of bleaching on boulders and water-washed surfaces, and the remains of high stage flood debris (e.g. Montgomery and Gran, 2001; Snyder et al., 2003; Whittaker et al., 2007a). The local channel slope measurements were measured over $10-30$ $\mathrm{m}$ as appropriate for the location in which they were taken. Repeat measurement variation associated with hitting the target with the laser range-finder was $\pm 0.2^{\circ}$.

Where exposed, the type of bedrock was documented and the rock mass strength measured (Figure 4 and 5). Intact rock strength was determined using a Schmidt hammer, from this the Selby rock mass strength index (Figure 4 [SRMS]) was calculated (Selby, 1980). Twenty-two Schmidt hammer rebound readings were made at each location and after the highest and lowest value were removed as outliers, the mean value was calculated. Schmidt hammer rebound values are a proxy for uniaxial compressive stress (e.g. Bursztyn et al., 2015). We chose this tool as it is portable and convenient for remote field locations, as measurements are easily and 
rapidly repeatable at a field site and because the values obtained are widely quoted in the literature (c.f. Goudie et al., 2006). Tensile strength or bedrock cohesion measurements typically require laboratory experiments that are very dependent on the typically small number of samples collected, although we return to this choice of bedrock strength characterisation technique in the discussion, below. In contrast, the SRMS represents a semi-quantitative assessment of rock mass strength based not just on rock strength but also the degree of weathering; ground water saturation; and the orientation, size and spacing of joints and bedding (Supplemental methods, Table S15). Values for the SRMS can range from $0-100$ with soils and unconsolidated rock having values of $<25$ (Selby, 1980; Sklar and Dietrich, 2001). Because the SRMS highlights relative differences in intact rock strength and hardness (Sklar and Dietrich, 2001), the method can give an indication of the bedrock resistance to erosion (Goudie, 2016). This is important because intact rock strength alone is sometimes argued to be a poor indicator of erodibility in heavily jointed lithologies (Whipple et al., 2000; Scott and Wohl, 2019). Paired Schmidt hammer / SRMS assessments were undertaken at 170 locations and data are presented both along the length of each river and shown as violin plots for the different lithological groups measured. For the five catchments where the clastic sedimentary units are exposed near the fault, we also estimated the first order grain size of sediments in transport in the river channel near the basin-fault using a Wolman point count technique on five available scaled photographs (supplementary material Figures S3, S4). Grain size data are not available for ca. 180 individual field sites.

\subsection{Hydraulic Scaling, Discharge and Unit Stream Power}

The first step to deriving unit stream power in the six rivers studied is to estimate the bankfull water discharge. As our rivers are not gauged, we used Manning's equation (Manning, 1891) in conjunction with our channel hydraulic geometry data near the faults to help estimate plausible fluid velocities and river discharges, Q, for each of the channels, where

$$
Q=v C=\frac{1}{n} H^{2 / 3} S^{1 / 2} C
$$

where $v$ is velocity in $\mathrm{ms}^{-1}, C$ is the cross-sectional area of flow $\left(\mathrm{m}^{2}\right), H$ is the flow depth $(\mathrm{m})$, and $n$ is a roughness coefficient. However estimates of bankfull 
discharge from point measures of hydraulic geometry vary both up and down over short length scales, while we are seeking a consistent and monotonic relationship between $Q$ and increasing downstream drainage area, $A$, for each river (c.f. Whittaker et al., 2007b). To obtain the evolution of catchment drainage areas for each river we used data from a 30 m DEM originally presented in Kent et al. (2017). We subsequently calculated the ratio of $A: Q$ at each site from our field hydraulic geometry measurements, and scaled our discharge estimates to the median value of this ratio. We repeated this process for all 6 rivers (supplementary material, Tables $S 7$ to S12). Finally, given that rainfall does not significantly vary across the local study area and all rivers are expected to have a similar discharge-drainage area scaling, we derived a mean scaling of $A: Q$ from all six rivers and used this ratio to obtain regionally consistent discharge values downstream that we use in all of our subsequent calculations (Table S14 and Fig. S1). This means that variations in stream power and eventual bedrock erodibility downstream, or between the catchments, are not driven by local point variations in discharge estimates or by unjustified differences in drainage area to discharge scaling (c.f. Whittaker et al., 2007). A full description of these calculations is included in the supplementary material.

Unit stream power, $\omega$ (eq. 2), represents the downstream rate of energy dissipation on the bed of a stream per unit channel width. In bedrock channels draining the footwalls of normal faults, existing studies have shown that unit stream power can and does scale with the magnitude and distribution of footwall uplift (e.g. Whittaker et al., 2007b; Cowie et al., 2008). We calculated unit stream power explicitly using field measures of channel width, as rivers crossing active faults are known not to obey typical hydraulic scaling that is often assumed in stream power calculations (Leopold and Maddock, 1953; Whittaker et al., 2007a). Our estimates of $Q$ from our fieldestimated regional discharge scaling are combined with the hydraulic geometry data collected downstream for each river (section 3.1) to derive the downstream distribution of specific stream power, $\omega$. As field-derived point measures of $\omega$ are particularly sensitive to local channel slope, we also averaged unit stream powers down-system over intervals of approximately $2 \mathrm{~km}$ to capture longer-wavelength downstream trends in stream power, consistent with previous workers (e.g. Lave \& Avouac, 2001; Whittaker et al., 2007 Cowie et al., 2008). The maximum reach- 
averaged stream power within the metamorphic lithologies was documented for each river. In addition, the maximum reach averaged stream power for a $2 \mathrm{~km}$ interval upstream of the active fault was recorded; this comprised clastic sedimentary lithologies for all channels apart from the Akçapınar River, which is only underlain by schists and gneisses. In each river, the knickpoint representing the farthest extent of the wave of incision lies between $6.5 \mathrm{~km}$ and $10 \mathrm{~km}$ upstream of the fault for all 6 catchments (Figure 3), so these data represent stream power averages in the zone upstream of the active fault that has already adjusted to the relative base level change (c.f. Kent et al., 2017).

\subsection{Comparison of Stream Powers, Throw Rates and Rock Strength Data}

We compare maximum reach-averaged stream power data in both the metamorphic rocks and in the sedimentary units upstream of the active faults with our rock mass strength data to evaluate our hypothesis that stream power should correlate with rock hardness or SRMS values. We also test whether unit stream power scales with the documented variation in fault throw rate, $U$, in both the sedimentary and metamorphic lithologies (c.f. Whittaker et al., 2007b; Cowie et al., 2008). As the rivers are documented to be undergoing a transient response to fault linkage (Kent et al., 2017) and there are no fault scarps in the channel where the rivers cross the basin bounding faults, indicating they are keeping pace with tectonics, we make the reasonable assumption that river incision rates equal fault uplift rates upstream of the basin-bounding faults and downstream of the knickpoints. The range-bounding fault is not always a single plane so a $2 \mathrm{~km}$ reach-averaged stream power estimate upstream of the fault zone enables us to average effectively across a number of data points near the faulted basin margin. However, for comparison, we also compare point measures of stream power where we locate the main strand of the fault with our throw rate data (supplementary material, Table S14 and Fig. S3). Given the structural configuration of the Bozdağ Range as a horst block (section 2), uplift across the footwall block is assumed to be approximately uniform in the absence of corroborating data, so we calculate minimum values of bedrock erodibility, $k_{b}$, for our lithological classes in each river (in units of $\mathrm{m} \mathrm{s}^{2} \mathrm{~kg}^{-1}$ ) as:

$k_{\mathrm{b}}=\omega_{\max } / U$ 
where $\omega_{\max }$ is the reach averaged maximum stream power in the $2 \mathrm{~km}$ upstream of the fault for the sedimentary lithologies, or the reach averaged in the metamorphic lithologies where they outcrop in the studied rivers.

\section{RESULTS}

\subsection{Relationship of Rock Strength to Lithology}

All six of the rivers studied drain the uplifted Bozdağ Range horst block, between bounding faults of the Gediz and Küçük Menderes grabens (Figure 1), and enter the main Gediz River, which runs roughly east-west through the Gediz Graben. Within each river is a tectonically induced knickpoint was identified by Kent et al. (2017) that does not correlate with known lithological boundaries. However, there are differences in the bedrock lithology across and along the studied rivers. For example, the Akçapınar River incises only through the metamorphic basement rocks upstream of the fault (Figure 3A), whereas the Yeniköy flows through the continental clastic lithologies for half its length (Figure 3B).

Schmidt hammer rebound readings (Figure 4) indicate that the metamorphic rocks are broadly ca. 2 times harder than the sedimentary units. Schmidt hammer readings for the metamorphic gneisses have an average of rebound value of 53 ( $n=$ $1180)$ and schists have an average Schmidt hammer value of $44(n=1200)$. In contrast the average rebound value of sediments is $28(n=880)$. This range of values is like those reported by other studies for similar rock types (i.e., Goudie, 2016). The SRMS (which also considers the orientation and characteristics of joints) of the metamorphic rocks is 1.3 times that of the sediments (Figure 4), with the gneiss having an average SRMS of $58(n=59)$, the schists an average of $56(n=$ $60)$, while the average SRMS for the sediments is $44(n=44)$.

There is also variability in the strength of the bedrock as determined from the Schmidt hammer and SRMS assessments along the length of the rivers, although the SRMS values show less variability and a smaller range in values than the Schmidt hammer rebound readings (Figure 5). Additionally, the metamorphic rocks have more variable rebound strengths than the sedimentary units. The greatest 
variability in rebound strength is evident along the Akçapınar (Figure 5A), Sartçay and the Bozdag (Figure 5B and $C$ ) in the west of the range, whereas the values from the metamorphic rocks of the Kabazlı, Yeniköy and Badınca rivers (Figure 5D - E) in the east are more similar. This observation potentially reflects the dominance of schist in the bedrock of the western rivers, whereas gneiss is more prevalent in the east. However, the overall rebound strength of the rocks is consistent with the regional mean. By contrast, rebound strength and SRMS values for sedimentary rocks exhibit remarkable downstream consistency with limited variability within individual rivers. Despite the observed downstream variation, it is evident that the metamorphic bedrock has greater rock strength than the sedimentary strata. We therefore proceed with these two lithological classes in the analysis below.

\section{2 Downstream Evolution in Stream Power}

The downstream evolution of unit stream power in each channel system gives a measure of how effectively each channel is keeping pace with uplift on the fault. For example, in the Akçapınar River (Figure 6a, Table 1) the stream power grows progressively from minimum values of $<100 \mathrm{Wm}^{2}$ in the headwaters to reachaveraged values of ca $1500 \mathrm{~W} / \mathrm{m}^{2}$, within the knickzone, $2 \mathrm{~km}$ from the active fault. At the fault, stream powers reduce to ca. $500 \mathrm{~W} / \mathrm{m}^{2}$ although the metamorphic bedrock is weaker and more fractured in this location (Figure 5a). By contrast, on the Sartçay River the stream power at the fault is only $105 \mathrm{~W} / \mathrm{m}^{2}$ in the sedimentary rocks near the fault (Figure 6b, Table 1). However, maximum and reach averaged stream powers of 2500 and $1600 \mathrm{~W} / \mathrm{m}^{2}$ respectively occurs $5 \mathrm{~km}$ upstream from the active fault in metamorphic rocks (gneisses), while values decrease after this peak towards the fault, corresponding to the river channel eroding through a sliver of schist and weaker sedimentary lithologies (Fig. 5b). Similar observations of peak stream power in the metamorphic rocks upstream of the fault, but within the knickzone can be made on the Bozdağ, Kabazlı, Yeniköy, Badınca Rivers (Figs. 6c-f).

As the sedimentary units have lower hardness and SRMS values than the metamorphic rocks in the Bozdağ Range we deduce rock type has a significant effect on the stream powers produced. While peak and maximum reach averaged stream power differ between the six rivers, which experience different fault uplift rates, a common trend in all the rivers is observed. Stream power significantly 
increases downstream of the knickpoint in the hard metamorphic rocks, and then declines rapidly at or towards the fault where soft sedimentary rocks are encountered (Figure $6 b-f)$. We also note that the rivers have low $\left(<100 \mathrm{~W} / \mathrm{m}^{2}\right)$ stream powers upstream of the knickpoint within the channel, even though the bedrock is hard. Moreover, we directly observe that the rivers are keeping pace with fault uplift at the basin margin due to the absence of fault scarps in the channels.

These data strongly suggest that bedrock lithology influences the downstream development of stream power. In particular, where the Akçapınar River is compared to the other rivers there is a measurable difference between the stream power at the fault (Table 1) because the Akçapınar incises through schist and gneiss along its whole length while the other rivers incise through weak clastic sediments in varying proportions of catchment area and channel length. Below we investigate this observation further.

\subsection{Influence of Rock Strength on Stream Power}

From field observations and rock strength measurements using a Schmidt hammer and the SRMS, it is obvious that the clastic sedimentary rocks within the catchment are on average weaker and more easily eroded than the metamorphic basement (Figs 4,5 ). In the rivers where there are sedimentary lithologies upstream of the active fault there is also a significant reduction in the stream power in this zone (Figure 6). Typically for Schmidt hammer rebound values of ca. 20 and SRMS values of ca. 50 , stream power is $<330 \mathrm{~W} / \mathrm{m}^{2}$. However, when stream power is compared to Schmidt hammer readings of the metamorphic bedrock, especially immediately upstream of the lithological boundary where maximum stream power is calculated, there is a broad trend of increasing stream power with increasing Schimdt hammer values (circles, Figure 7a). A similar but weaker relationship can be observed for an increase in stream power with higher SRMS values.

If we assume that the maximum reach-averaged stream powers developed in both the metamorphic and sedimentary rocks are sufficient to balance uplift on the active fault (Equation 3), we can use this data (and associated uncertainty) to make a first order estimate of $k_{b}$ as a function of rock strength (Equation 2, Figure 7b). This calculation suggests that $k_{\mathrm{b}}=2.2-6.3 \times 10^{-14} \mathrm{~m} \mathrm{~s}^{2} \mathrm{~kg}^{-1}$ in the metamorphic rocks and 
$503 k_{b}=1.2-15 \times 10^{-13} \mathrm{~m} \mathrm{~s}^{2} \mathrm{~kg}^{-1}$ for the sedimentary units - a difference of up to 30

504 times in the value of implied bedrock erodibility is obtained for a less than 3 fold variation in Schmidt hammer rebound value. This result suggests that relatively small differences in rock mass strength measurements can translate into very large differences in long-term bedrock erodibility. However, we also note that for any given rock strength there can be up to a > 3 fold difference in the calculated stream power at the locality of measurement (Figure 7a). For example, on the Bozdağ River the highest stream power developed in a ca. $2 \mathrm{~km}$ metamorphic reach is $2895 \mathrm{Wm}^{-2}$ with an average Schmidt hammer reading of 45 and average SRMS of 65. Yet, for the Badınca the Schmidt hammer and SRMS values are similar to the Bozdağ at 46 and 66, respectively, but the maximum stream power developed is $962 \mathrm{Wm}^{-2}$ (Table1). Consequently, rock strength is not the only parameter that influences the stream power of the river. Given that the Bozdağ is experiencing throw rates of 2 mmyr $^{-1}$ and the Badınca throw rates of $0.7 \mathrm{mmyr}^{-1}$ it is expected that the variation in throw rates along strike of the active fault is also a significant control on the stream power.

\subsection{The Influence of Throw Rate on Stream Power}

Assuming river incision is keeping pace with tectonic uplift in the vicinity of the fault, we compare stream powers within the knickzone upstream of the fault to evaluate if along-strike variations in throw rate can account for the differences in stream power observed, given that rock strength variation alone does not fully explain the variations in unit stream power observed. As the clastic sediments within the catchment are weaker and more erodible than the metamorphic bedrock, we first compare the effect of tectonic throw rate on the maximum reach average stream power in the knickzone (Figure 8a) as in all cases this value lies within the harder metamorphic lithology. The Bozdağ Range is an uplifting horst block likely with broadly uniform uplift (Kent et al., 2016), so the uplift rate experienced by the river in the area of peak stream power should be representative of the magnitude of the throw rate at the fault. If the tectonic uplift occurring on the southern margin of the Gediz Graben is the only factor determining the stream power of the rivers where metamorphic lithologies dominate (and hence their incision can be described a simple 'detachment-limited' erosion model), it would be expected that the stream power would be proportional to the estimated uplift rate. The present-day throw rates determined by Kent et al. (2017) show a $~ 3$ fold difference in the throw rates 
between the rivers, so in theory it should be possible to observe a similar scaling in the stream power.

We do observe a positive correlation between throw rate and the maximum stream power developed in the metamorphic rocks in the knickzone upstream of the fault (Figure 8a). We note there is a factor of three difference in maximum reach averaged unit stream power between the river eroding the slowest slipping part of the fault block (the Badınca; $972 \mathrm{~W} / \mathrm{m}^{2}$ ) and the fastest slipping (Bozdağ River; 2985 $\mathrm{W} / \mathrm{m}^{2}$ ), for a throw rate of 0.7 and $2.1 \mathrm{mmyr}^{-1}$, respectively. However, the Akçapınar, Kabazlı and Sartçay rivers have somewhat lower stream power than a simple linear scaling might suggest between these end-members. Some of this variation may reflect bedrock erodibility differences, captured imperfectly in the SRMS and Schmidt hammer rebound measurements shown in Figure $7 \mathrm{a}$ and/or a non-linear relationship between stream power and throw rate upstream of the fault. The Yeniköy (white symbol, Figure 8a) is an outlier to this trend. The peak reach-averaged stream power developed in the metamorphic rocks along the Yeniköy is approximately a factor of 2 smaller than for other rivers subjected to similar uplift rates (Figure 8a; Table 1). We note there is a significant amount of clastic sediment observed in this river and we return to this observation in the discussion.

The same type of analysis as above can be undertaken to examine the impact of sedimentary bedrock on the stream power of the rivers near the fault (Figure 8b). Where sedimentary rocks are present in the $2 \mathrm{~km}$ upstream of the fault (all rivers bar the Akçapınar), the stream power is markedly lower than in the metamorphic lithologies $\left(<330 \mathrm{Wm}^{-2}\right)$. But as figure 7 a shows, the values do not appear to scale with the (relatively limited) variation in Schmidt hammer rebound or SRMS values. However, the reach-averaged stream power of rivers incising through sedimentary bedrock in the $2 \mathrm{~km}$ upstream of the fault also does not increase with throw rate, contrary to the way that the peak reach-averaged stream power does in the metamorphic rocks (Figure 8b). In four of the rivers, the measured stream power within the sediments are lower than the stream power of the Badınca River, even though this is the river crossing the part of the fault with the lowest slip rate; only in the Sartçay River (slipping at $1.85 \mathrm{~mm} / \mathrm{yr}$ ) is higher stream power than the Badınca recorded. Point measurements of stream power in the sedimentary units at the fault 
571 lead to identical conclusions, with no scaling between stream power and fault throw

572 rate (supplementary material, Fig. S3).

573

574 Consequently, while fault throw rates exert a first order control over the stream 575 power within the metamorphic lithology present upstream in all rivers, which is 576 consistent to first order with a detachment limited model of erosion. The variations in 577 unit stream power do not simply explain the ability of the rivers to cut across the 578 sedimentary rocks in the footwall of the Gediz Graben where throw rates vary by up 579 to a factor of 3 , we return to this observation in the discussion below (c.f. Cowie et 580 al., 2008).

581

582

583

\section{ANALYSIS AND DISCUSSION}

584

\section{1 Bedrock erodibility and lithological controls on fluvial incision}

586

Our results demonstrate that both bedrock strength and fault throw rate influence the magnitude of unit stream power developed upstream of active fault segments in the Gediz Graben of Turkey. It is well established that bedrock lithology should be an important a factor in determining the rate and style of landscape response to a change in relative base level (Stock and Montgomery, 1999; Reneau, 2000; Bishop et al., 2005; Brocard and van der Beek, 2006; Anthony and Granger, 2007; Cook et al., 2009, Kent et al., 2017, Yanites et al., 2017, Zondervan et al., 2020a). However, the precise nature of the control exerted on river response to tectonic perturbation remains an outstanding issue (Crosby and Whipple, 2006; Anthony and Granger, 2007; Haviv et al., 2010; Whittaker and Boulton, 2012). This study provides further insight into the nature of this control and provides new constraints on the links between theoretical estimates of bedrock erodibility and physical measurements of rock mass strength.

The magnitude and range of bedrock erodibilities in published studies varies widely, both as a function of study location and the erosion law chosen (Stock and Montgomery, 1999; Zondervan et al., 2020a). In this study, assuming a unit stream power erosion law in which channel width and discharge are derived directly from 
field data, we find that there is a significant difference in $k_{b}$ between the two broad rock types, where $k_{\mathrm{b}}=2.2-6.3 \times 10^{-14} \mathrm{~m} \mathrm{~s}^{2} \mathrm{~kg}^{-1}$ in the metamorphic rocks and $k_{\mathrm{b}}=$ $1.2-15 \times 10^{-13} \mathrm{~m} \mathrm{~s}^{2} \mathrm{~kg}^{-1}$ for the sedimentary units. These values are comparable to, but greater than the bedrock erodibilities of $1.8 \pm 0.3 \times 10^{-14}$ and $6 \pm 2 \times 10^{-15} \mathrm{~m} \mathrm{~s}^{2}$ $\mathrm{kg}^{-1}$ recently derived by Zondervan et al. (2020a) for conglomerates and limestones, respectively, upstream of the East Eliki fault on the southern margin of the Gulf of Corinth, Greece, in a study where a similar methodology has been used. While it is notable that order of magnitude differences in bedrock erodibility are obtained between the metamorphic rocks and the sedimentary units for relatively limited differences in measured rock strength, it is equally important to observe that these bedrock erodibilities are up to 10 orders of magnitude less than values that have been used in numerical modelling studies where units of erodibility can be compared directly (Roy et al., 2015; Yanites et al., 2017). Because landscape response times to tectonics, expressed for instance in terms of knickpoint retreat rates, scale directly with bedrock erodibility (e.g. Whittaker and Boulton, 2012), these differences imply landscape response times that are geomorphically long (i.e. multi-million year timescales for catchments of the scale studied here). Consequently, we argue that our results underline the importance of deriving field constraints on bedrock resistance to erosion much more widely.

The impact of lithological variation on bedrock erodibility between the sedimentary and metamorphic rock types investigated here has to be contextualised with respect to the 'many orders of magnitude difference' in rock resistance to fluvial incision that some authors have obtained, using a more generalised form of the stream power erosion law (Eq. 1). For example, Stock and Montgomery (1999) studied the effect of lithology on the $\mathrm{K}$ parameter in this simple form of the unit stream power model where erodibility values are expressed in units of $\mathrm{m}^{(1-2 \mathrm{~m})} \mathrm{yr}^{-1}$. They noted that $\mathrm{K}$ varied over five orders of magnitude between mudstones and volcaniclastic rocks from Japan and California $\left(10^{-2}\right.$ to $\left.10^{-5} \mathrm{~m}^{0.2} \mathrm{yr}^{-1}\right)$ and granitoids and metasediments in Australia $\left(10^{-6}\right.$ to $\left.10^{-7} \mathrm{~m}^{0.2} \mathrm{yr}^{-1}\right)$, although the proportion of the variation owing to climate was unresolved because precipitation-driven discharge scaling with drainage area was not considered. Brocard and Van der Beek (2006) also determined that for bedrock rivers in French Alpine rivers $\mathrm{K}$ should fall between $1.8-4.7 \times 10^{-5} \mathrm{~m}^{0.4} \mathrm{yr}^{-1}$ for marl and between $1.1-3.7 \times 10^{-5} \mathrm{~m}^{0.4} \mathrm{yr}^{-1}$ for limestone, whereas van der Beek 
and Bishop (2003) determined that for a river crossing crystalline basement rocks in SE Australia that $\mathrm{K}=7 \times 10^{-7} \mathrm{~m}^{0.4} \mathrm{yr}^{-1}$. $\mathrm{K}$ parameters determined for crystalline rocks on the Pacific Islands of Makira and Guadalcanal also fall in the range $1 \times 10^{-5}$ to 5 $\mathrm{x} 10^{-8} \mathrm{~m}^{0.1} \mathrm{yr}^{-1}$ (Boulton, 2020). Similarly, the knickpoint retreat rate data of Whittaker and Boulton (2012) imply $\mathrm{K}$ of $10^{-6}$ to $10^{-7} \mathrm{yr}^{-1}$ assuming $m=0.5$. Comparison with our results expressed in a drainage-area dependent form equivalent to Eq. 1 suggests $K$ ca. $10^{-7} \mathrm{yr}^{-1}$ in the metamorphic rocks and values $>10^{-6} \mathrm{yr}^{-1}$ in the sedimentary units of the Bozdağ Range. These studies therefore indicate that $\mathrm{K}$ does vary markedly worldwide, and even if discharge data are known or derived, allowing for climate differences to be accounted for, our results support Stock and Montgomery's (1999) initial conclusion that the timescale of landscape evolution must vary greatly with lithology. A key area for future work is to link modelling studies with realistic long-term values of bedrock erodibility, ideally derived from locations where the timescale of erosion rates can be derived independently.

\subsection{Rock mass strength, bedrock erodibility}

Bedrock erodibility is not a physical parameter that can be measured directly in the same way as compressive or tensile strength of bedrock, or the density of fractures (e.g. Bursztyn et al., 2015; Zondervan et al., 2020a,b). It is also true that mapped lithological units (or lithological groups as used here) typically can encompass significant variations in local lithofacies and bedrock resistance to fluvial erosion at a map scale (c.f. Yanites et al., 2017). Consequently, our analysis is intended to describe differences in rock resistance to incision between broad rock types at a coarse resolution. In this study, a regional variation in Schmidt hammer rebound values of a factor of ca. 2 between clastic sedimentary rocks and metamorphic schists and gneisses produces greater than an order of magnitude difference in $k_{b}$ (Figure 7b). At a finer resolution, small variations in SRMS index appear to be linked to marked variations in unit stream power developed upstream of the faults (Figures 6 and $7 \mathrm{a}$ ). The length scale over which such variations in rock strength matter for governing landscape evolution over $10^{5}$ to $10^{6}$ years remains unresolved. Variations in fracture density have been clearly linked to the local or reach scale morphology of rivers (see Scott and Wohl, 2019 for an extensive review), yet at large scales (101$10^{3} \mathrm{~km}$ ) numerical analyses suggest that the spectral power in river long profiles is not controlled by lithology (Roberts, 2019). Here we suggest that a broad grouping of 
672 two main lithotypes on the 1 to $10 \mathrm{~km}$ scale is sufficient to illustrate the important role 673 of lithology in driving landscape response to tectonics for a fault block where the length scale of the footwall rivers is of comparable magnitude to the spatial variations in rock strength.

677 Nonetheless, a marked variation in bedrock erodibility is calculated in some 678 instances, even where Schmidt hammer rebound values are similar (Figure 7). 679 These observations raise the question of what are the most appropriate physical measures of rock strength that correlate with estimates of bedrock erodibility derived from field examples of landscape incision over timescales of $10^{4}$ to $10^{6}$ years. The Schmidt hammer is a quick, portable and convenient tool to estimate effective compressive strength in a field setting (c.f. Zondervan et al., 2020a), but theoretical and observational studies suggest that tensile rock strength might more effectively represent the resistance of bedrock to the impact of clasts in a river as previously noted (Sklar and Dietrich, 2001; Bursztyn et al., 2015). However, lab measurements on individual rock samples do not typically capture the full range of factors such as joint density and orientation that influence rock strength and bedrock erodibility at scales greater than the sample size (e.g. greater than a few centimetres), while it is hardly practical to quantify joint densities at high resolution across an entire catchment that may have a drainage area of tens or hundreds of square kilometres. The SRMS index does include a range of jointing parameters, but only in a semiquantitative sense, and it was not originally designed to measure bedrock resistance to fluvial incision. In this study there appears to be little correlation of Selby jointing sub-parameterisation with down-system distributions of stream power (Supplementary Data Tables S1 to S6). At the same time, relatively small variations in measurements of physical rock strength here translate into order of magnitude differences in long-term bedrock erodibility, suggesting that landscapes upstream of active normal faults are highly sensitive to rock strength differences. We also note that in this study the SRMS index in general shows less variability in rock strength between lithological units than our Schmidt hammer rebound values alone, so although this rock strength parameterisation is widely used (c.f. Whittaker et al., 2007b; Zondervan et al., 2020), we would suggest that it is not a particularly sensitive measure of long-term bedrock erodibility captured by $k_{b}$. Consequently, an outstanding area of further work is to probe further what physical and in situ 
measures of rock strength correlate effectively with estimates of bedrock erodibility derived from constraints on long-term landscape evolution over a range of spatial scales, and to further investigate if composite measures of rock strength such as the SRMS can be adapted to better capture differences in long-term substrate resistance to fluvial erosion.

\subsection{Stream Powers, Throw Rates and Sediment Transport Capacity}

In this study, for the clastic sedimentary units upstream of the fault, stream power is markedly lower than in the metamorphic rocks for all six rivers (Figure 7a). This observation is consistent with qualitative observations of the friable nature of these lithologies compared to the metamorphic rocks, and with quantitative observations of lower Schmidt hammer rebound and SRMS values. However, our results also show that there is not a clear correlation between estimated fault throw rate and stream power at the fault in the sedimentary lithologies (Fig. 8b), which is what a simple unit stream power model of fluvial incision would predict for rivers incising uniform lithology. Therefore, our results raise the question of whether a simple detachmentlimited erosion law is too basic to characterise the time-integrated incisional dynamics of these rivers.

One consideration could be that the Schmidt hammer rebound values and SRMS measures are not very good at picking up relative variations in bedrock strength in soft lithologies, particularly in cases where the hammer does not measure a marked rebound. However, an alternative possibility is that the nature of the bedrock itself also influences the long-term erosional dynamics of the channels. A version of this effect has previously been noted by Cowie et al. (2008), in a comparative study of rivers crossing active normal faults each with broadly similar lithologies near the Gulf of Evia, Greece and in the Central Apennines. In this research, it was found that increasing bed shear stresses, calculated from hydraulic geometry measurements, did not scale with increased fault throw rates, despite clear evidence of the individual rivers keeping pace with the rate of faulting. Instead, the authors argued that increasing sediment flux down-system, derived from outcropping conglomerates, provided a 'tools' effect that markedly boosted the ability of the river to incise across the fault. 
In our case all but one of the rivers are incising across Neogene poorly-consolidated clastic sedimentary units near the faults, rocks which were originally of fluvial or alluvial fan origin. Based on our results in Figure 8b, we explore the additional hypothesis that in the downstream reaches of five of the studied rivers, the friable clastic bedrock substrate provides an abundant supply of sediment and in effect, the river may be limited in its ability to incise by its capacity to transport the poorly cemented clastic material that effectively forms the substrate. We do not know the long term sediment supply relative to the discharge history of the river, but if this is the case, then we might expect the rivers to be configured such that their sediment transport capacity, $Q_{c}$, is greater where fault throw rates are larger. One way to check if this true for the sedimentary bedrock units is to use the channel hydraulic geometry data to determine a dimensional Meyer-Peter-Muller bedload transport capacity in $\mathrm{kgs}^{-1}$ which can be calculated (Whittaker, 2007) as:

$754 Q_{c}=\left[\rho_{s}\left(\frac{\rho_{s}-\rho_{w}}{\rho_{w}} g D^{3}\right)^{\frac{1}{2}} C\left(\tau^{*}-\tau_{c}^{*}\right)^{\frac{3}{2}}\right] * W$

755

756

757

758

759

760

761

762

763

764

765

766

767

where $\rho_{s}$ and $\rho_{w}$ are the densities of sediment and water, respectively; $D$ is the median grain-size; $T^{*}$ is the dimensionless shear stress (estimated from $\frac{H S}{D \rho_{x}}$ where $\rho_{\mathrm{x}}$ represents the excess sediment density of 1.65); $\mathrm{T}^{*}{ }_{\mathrm{C}}$ is the critical Shields stress for entrainment of gravel, for which we use a constant of 0.06 (e.g. Mueller and Pitlick, 2005) and $C=3.97$ based on the re-analysis by Wong and Parker (2006). To do this, we require estimates of grain size in the rivers near the fault. We do not have data on sediment calibre for the majority of our field sites, but we have some photo estimates for 5 sites in the downstream reaches of the rivers near the fault (Methods, Supplementary Material Fig. S3 and Fig. S4). We take this data to be representative of grain size, to first order, for the $2 \mathrm{~km}$ reaches upstream of the range bounding fault.

This additional analysis (Figure 9) indicates that instantaneous sediment transport capacity, averaged for a $2 \mathrm{~km}$ reach upstream of the fault in the clastic sedimentary units, is strongly dependent on fault throw rate. Transport capacities vary from ca. $100 \mathrm{~kg} / \mathrm{s}$ for the river crossing the slowest slipping section of the fault to $>300 \mathrm{~kg} / \mathrm{s}$ for the river crossing the fastest slipping section of the fault (which has a throw rate three times greater). The Yeniköy River, which had relatively low stream powers in 
772 both the sedimentary and metamorphic rocks fits well with the trend of the data.

773 These data are consistent with the hypothesis that the rivers incising into poorly consolidated clastic bedrock are configured to transport more sediment where fault slip rates are greater. However the relationship between sediment transport capacity and uplift rate shown in figure 9 is not linear and we do not have any information on the frequency and the magnitude of sediment transport events or the exact locus of sediment sourcing, although it was likely wetter in the region at the last glacial maximum (Kent et al., 2017). In addition, we do not know the ratio of the long term sediment flux to the transport capacity, which potentially may have varied over glacial-interglacial timescales and will have determined the time-averaged export of sediment from the catchments.

Nevertheless, a sediment transport rate of e.g. $200 \mathrm{~kg} / \mathrm{s}$ would enable a river to discharge ca. $7000 \mathrm{~m}^{3}$ of sediment if active at bankfull capacity for one day a year, given $\rho_{\mathrm{s}}=2400-2600 \mathrm{~kg} / \mathrm{m}^{3}$, which would represent 'erosion' rates of $>1.4 \mathrm{~mm} / \mathrm{yr}$ if the sediment was uniformly derived from a plausible clastic bedrock catchment area of e.g. $5 \mathrm{~km}^{2}$. The rivers in this study are not gauged, but based on this analysis, we interpret our results to indicate that even where rivers are documented to incise bedrock upstream of fast-slipping faults, the presence of clastic sedimentary rocks can influence fluvial responses to tectonics, not just in terms of absolute rock strength relative to 'harder' lithologies, but also by supplying channels with selfderived clastic detritus that can influence long-term erosional dynamics. Resolving the nature of this control more generally requires a system in which sediment discharge histories can be determined independently and where multiple bedload grain size data points are available.

\section{CONCLUSIONS}

The Gediz Graben in Western Turkey is a Neogene extensional graben that experienced an increase in fault slip rates $\sim 0.8 \mathrm{Ma}$, causing a wave of river incision to propagate through rivers draining transversely across the faulted basin margin. These rivers incise two main lithological groups - metamorphic gneisses and schists and more friable Neogene clastic sedimentary formations. The channels are responding transiently to this tectonic perturbation by changing their geometry and planform shape up and downstream of knickpoints in the rivers. 
806 For six selected rivers representing different bedrock lithologies and fault slip rates, 807 unit stream powers were calculated and bedrock strength measured using field data. 808 Similar downstream trends are seen in each case. In the headwaters the stream 809 powers remain low (under $150 \mathrm{~W} / \mathrm{m}^{2}$ ) until the knickpoint. Downstream of the 810 knickpoint the stream powers rise significantly to peak values found within the 811 metamorphic bedrock. However, where the channel incises the Neogene clastic sediments downstream towards the active fault, stream powers decrease markedly. Schmidt hammer rebound values and Selby rock mass strength (SRMS) measurements demonstrate that the metamorphic rocks are around $2 x$ harder than the sediments while the stream powers in the sedimentary lithologies are significantly lower than in the metamorphic basement. Based on our observation that the rivers are keeping pace with the basin bounding fault and independent estimates of fault throw rate, we use this data to calculate the bedrock erodibility $k_{\mathrm{b}}$ of the two main lithological groups identified. Overall, $k_{\mathrm{b}}$ shows $>30$ fold variation between sedimentary and metamorphic rocks corresponding to $a<3$ fold variation in Schmidt hammer rebound strength, suggesting that small differences in rock strength translate into significant differences in long-term bedrock erodibility and landscape response time. We also note that our field-derived values for $k_{\mathrm{b}}$ are smaller than values that have been used in modelling studies or derived from other field measures, highlighting the need for further research into this poorly constrained parameter.

Although our data show that lithology plays a key role in modulating stream powers upstream of the basin bounding fault, we do find that the rivers exhibit peak stream powers in the stronger and more resistant metamorphic rocks and these values scale with throw rate, suggesting that where the rivers erode metamorphic lithologies the detachment-limited models of erosion can predict bedrock incision rate. We also demonstrate that in the reaches where the rivers incise the poorly consolidated clastic bedrock, unit stream power shows limited correlation to the throw rate. However, when the bedload sediment transport capacity of these rivers is compared to the throw rate there is a trend of increasing transport capacity with increasing throw rate on the fault, and we suggest that the supply of easily erodible clastic material directly from the bedrock has a profound effect on the behaviour of our 
studied rivers. Consequently, we argue that bedrock type influences landscape response to faulting, not just in terms of the erodibility of the substrate, but also in terms of the dynamics of the long-term incision process itself.

\section{ACKNOWLEDGEMENTS}

We would like to thank the University of Plymouth for the funding of Dr Kent's PhD research and Jamie Quinn (UoP) for assistance in drafting figure 1. We thank the associate editor, John Jansen, and the reviewers Maggie Ellis Curry and Joel Scheingross for careful and insightful reviews.

\section{REFERENCES}

Allen, G. H., Barnes, J. B., Pavelsky, T. M., and Kirby, E., 2012. Bedrock Channel Adjustment to Variations in Tectonics and Lithology at the Himalayan Front in Northwest India. In AGU Fall Meeting Abstracts, v. 1, p. 0992.

Allen, G. H., Barnes, J. B., Pavelsky, T. M., and Kirby, E., 2013. Lithologic and tectonic controls on bedrock channel form at the northwest Himalayan front. Journal of Geophysical Research: Earth Surface, v. 118(3), p. 1806-1825.

Ambraseys, N. N., 2009. Earthquakes in the Mediterranean and Middle East-a multidisciplinary study of seismicity up to 1900. Cambridge University Press, Cambridge.

Anthony, D. M., and Granger, D. E., 2007. An empirical stream power formulation for knickpoint retreat in Appalachian Plateau fluviokarst. Journal of Hydrology, v. 343(3), p. 117-126.

Arpat E, Bingöl E. 1969. Ege Bölgesi graben sisteminin gelişimi üzerine düşünceler. MTA Dergisi 73: 1-8.

Attal, M., Tucker, G.E., Whittaker, A.C., Cowie, P.A., and Roberts, G.P., 2008, Modelling fluvial incision and transient landscape evolution: influence of dynamic channel adjustment, Journal of Geophysical Research, 113, F03013, doi:10.1029/2007JF000893

Bernard T, Sinclair HD, Gailleton B, Mudd SM, and Ford M., 2019. Lithological control on the post-orogenic topography and erosion history of the Pyrenees. Earth Planet Science Letters, v. 518, p. 53-66.

Bishop, P., Hoey, T. B., Jansen, J. D., and Artza, I. L., 2005. Knickpoint recession rate and catchment area: the case of uplifted rivers in Eastern Scotland. Earth Surface Processes and Landforms, v. 30(6), p. 767-778.

Braun, J., and Sambridge, M., 1997. Modelling landscape evolution on geological time scales: a new method based on irregular spatial discretization. Basin Research, 9(1), 27-52. 
Brocard, G. Y., and Van der Beek, P. A., 2006. Influence of incision rate, rock strength, and bedload supply on bedrock river gradients and valley-flat widths: Field-based evidence and calibrations from western Alpine rivers (southeast France). Geological Society of America Special Papers, v. 398, p. 101-126.

Boulton, S.J., 2020. Geomorphic Response to Differential Uplift: River Long Profiles and Knickpoints From Guadalcanal and Makira (Solomon Islands). Frontiers in Earth Science 8:10 https://doi.org/10.3389/feart.2020.00010

Bozkurt, E., 2003. Origin of NE-trending basins in western Turkey, Geodinamica Acta v. 16, p. 61-81.

Bozkurt, E., and Sözbilir, IR, H., 2004. Tectonic evolution of the Gediz Graben: field evidence for an episodic, two-stage extension in western Turkey. Geological Magazine, v. 141(01), p. 63-79.

Bursztyn, N., Pederson, J.L., Tressler, C., Mackley, R.D. and Mitchell, K.J., 2015. Rock strength along a fluvial transect of the Colorado Plateau-quantifying a fundamental control on geomorphology. Earth and Planetary Science Letters, v. 429, p.90-100.

Buscher, J. T., Hampel, A., Hetzel, R., Dunkl, I., Glotzbach, C., Struffert, A., Akal, C., and Rätz, M., 2013. Quantifying rates of detachment faulting and erosion in the central Menderes Massif (western Turkey) by thermochronology and cosmogenic 10Be. Journal of the Geological Society, 170(4), 669-683.

Çiftçi, N. B., and Bozkurt, E,. 2009a. Pattern of normal faulting in the Gediz Graben, SW Turkey. Tectonophysics, v. 473(1), p. 234-260.

Çiftçi, N. B., and Bozkurt, E., 2009b. Evolution of the Miocene sedimentary fill of the Gediz Graben, SW Turkey. Sedimentary Geology, v. 216(3), p. 49-79.

Cook, K. L., Whipple, K. X., Heimsath, A. M. and Hanks, T. C., 2009. Rapid incision of the Colorado River in Glen Canyon-insights from channel profiles, local incision rates, and modelling of lithologic controls. Earth Surface Processes and Landforms, v. 34(7), p. 994-1010.

Cowie, P. A., Whittaker, A. C., Attal, M., Roberts, G., Tucker, G. E., Ganas, A., 2008. New constraints on sediment-flux-dependent river incision: Implications for extracting tectonic signals from river profiles. Geology, v. 36(7), p. 535-538.

Croissant, T. and Braun, J., 2014. Constraining the stream power law: a novel approach combining a landscape evolution model and an inversion method. Earth Surface Dynamics, v. 2, p. 155-166.

Crosby, B. T., and Whipple, K. X., 2006. Knickpoint initiation and distribution within fluvial networks: 236 waterfalls in the Waipaoa River, North Island, New Zealand. Geomorphology, v. 82, p. 16-38.

D'Arcy M. \& Whittaker, A.C., 2014, Geomorphic constraints on landscape sensitivity to climate in tectonically active areas, Geomorphology, v. 204, p. 366-381. doi: 10.1016/j.geomorph.2013.08.019 
Duvall, A., Kirby, E., and Burbank, D., 2004. Tectonic and lithologic controls on bedrock channel profiles and processes in coastal California. Journal of Geophysical Research: Earth Surface, 109(F3).

Eyidoğan, H. and Jackson, J., 1985. A seismological study of normal faulting in the Demirci, Alaşehir and Gediz earthquakes of 1969-70 in western Turkey: Implications for the nature and geometry of deformation in the continental crust. Geophysical Journal International, 81(3), pp.569-607.

Ferrier, K. L., Huppert, K. L., and Perron, J. T., 2013. Climatic control of bedrock river incision. Nature, v. 496(7444), p. 206-209.

Finnegan, N. J., Roe, G., Montgomery, D. R., and Hallet, B., 2005. Controls on the channel width of rivers: Implications for modeling fluvial incision of bedrock.Geology, v. 33(3), p. 229-232.

Finnegan, N.J., Sklar, L.S. and Fuller, T.K., 2007. Interplay of sediment supply, river incision, and channel morphology revealed by the transient evolution of an experimental bedrock channel. Journal of Geophysical Research: Earth Surface, v. 112(F3).

Forte, A.M., Yanites, B.J. and Whipple, K.X., 2016. Complexities of landscape evolution during incision through layered stratigraphy with contrasts in rock strength. Earth Surface Processes and Landforms, v. 41(12), p.1736-1757.

Gessner, K., Piazolo, S., Güngör, T., Ring, U., Kröner, A., and Passchier, C. W., 2001. Tectonic significance of deformation patterns in granitoid rocks of the Menderes nappes, Anatolide belt, southwest Turkey. International Journal of Earth Sciences, v. 89(4), p. 766-780.

Goldrick, G., and Bishop, P., 1995. Differentiating the roles of lithology and uplift in the steepening of bedrock river long profiles: an example from southeastern Australia. The Journal of Geology, v. 103(2), p. 227-231.

Goudie, A.S., 2016. Quantification of rock control in geomorphology. Earth-science reviews, v. 159, p.374-387.

Goudie, A.S., 2006. The Schmidt Hammer in geomorphologial research. Progress in Physical Geography, v. 30. p. 703-718. 10.1177/0309133306071954.

Hancock, G. R., Willgoose, G. R., and Evans, K. G., 2002. Testing of the SIBERIA landscape evolution model using the Tin Camp Creek, Northern Territory, Australia, field catchment. Earth Surface Processes and Landforms, v. 27(2), p. 125-143.

Haviv, I., Enzel, Y., Whipple, K. X., Zilberman, E., Matmon, A., Stone, J., and Fifield, K. L., 2010. Evolution of vertical knickpoints (waterfalls) with resistant caprock: Insights from numerical modeling. Journal of Geophysical Research: Earth Surface (2003-2012), v. 115(F3). 
Hetzel, R., Ring, U., Akal, C. and Troesch, M., 1995. Miocene NNE-directed extensional unroofing in the Menderes Massif, southwestern Turkey. Journal of the Geological Society, 152(4), pp.639-654.

Howard, A. D., 1994. A detachment- limited model of drainage basin evolution. Water resources research, v. 30(7), p. 2261-2285.

Kent, E., Boulton, S. J., Stewart, I. S., Whittaker, A. C., and Alçiçek, M. C., 2016. Geomorphic and geological constraints on the active normal faulting of the Gediz (Alaşehir) Graben, Western Turkey. Journal of the Geological Society, v. 173(4), p. 666-678.

Kent, E., Boulton, S. J., Whittaker, A. C., Stewart, I. S., and Alçiçek, M.C., 2017. Normal fault growth and linkage in the Gediz (Alaşehir) Graben, Western Turkey, revealed by transient river long- profiles and slope- break knickpoints. Earth Surface Processes and Landforms, v. 42(5), p. 836-852.

Kirby, E., \& Whipple, K. 2012. Expression of active tectonics in erosional landscapes. Journal of Structural Geology, v., 44, p. 54-75. 10.1016/j.jsg.2012.07.009.

Knighton, A. D., 1998. Fluvial Forms and Processes: A New Perspective. Routledge, London and New York, $383 \mathrm{p}$.

Lague, 2014. The stream power river incision model: evidence, theory and beyond Earth Surface Processes and Landforms, v. 39, p. 38-61.

Lavé, J., and Avouac, J. P., 2001. Fluvial incision and tectonic uplift across the Himalayas of central Nepal. Journal of Geophysical Research: Solid Earth, v. 106(B11), p. 26561-26591.

Leopold, L. B., and Maddock, T., 1953. The hydraulic geometry of stream channels and some physiographic implications. U. S. Geological Survey Professional Paper v. 252 , p. $1-57$.

Manning, R., 1891. On the flow of water in open channels and pipes, Transactions, Institution of Civ. Eng. Ireland, Dublin, v. 20, p. 161-207.

Montgomery, D. R., and Gran, K. B., 2001. Downstream variations in the width of bedrock channels. Water Resources Research, v. 37(6), p. 1841-1846.

Mueller, E. R., and Pitlick, J., 2005. Morphologically based model of bed load transport capacity in a headwater stream. Journal of Geophysical Research: Earth Surface, v. 110(F2).

Okay, A. I., and Satir, M., 2000. Coeval plutonism and metamorphism in a latest Oligocene metamorphic core complex in northwest Turkey. Geological Magazine, v. $137(5)$, p. $495-516$.

Oner, Z., and Dilek, Y., 2011. Supradetachment basin evolution during continental extension: The Aegean province of western Anatolia, Turkey. Geological Society of America Bulletin, v. 123(11-12), p. 2115-2141. 
Pechlivanidou, S., Cowie, P., Hannisdal, B., Whittaker, A., Gawthorpe, R., Pennos, C., \& Riiser, O. 2018. Source-to-sink analysis in an active extensional setting: Holocene erosion and deposition in the Sperchios rift, central Greece. Basin Research. V. 30. p. 522-543, doi: 10.1111/bre.12263.

Perne, M., Covington, M. D., Thaler, E. A., and Myre, J. M., 2017. Steady state, erosional continuity, and the topography of landscapes developed in layered rocks. Earth Surface Dynamics, v. 5(1), p. 85-100.

Purvis, M., and Robertson, A., 2004. A pulsed extension model for the NeogeneRecent E-W-trending Alaşehir Graben and the NE-SW-trending Selendi and Gördes Basins, western Turkey. Tectonophysics, v. 391(1-4), p. 171-201.

Purvis, M., and Robertson, A., 2005. Sedimentation of the Neogene-Recent Alaşehir (Gediz) continental graben system used to test alternative tectonic models for western (Aegean) Turkey. Sedimentary Geology, v. 173(1-4), p. 373-408.

Ring, U. W. E., Johnson, C., Hetzel, R., and Gessner, K., 2003. Tectonic denudation of a Late Cretaceous-Tertiary collisional belt: regionally symmetric cooling patterns and their relation to extensional faults in the Anatolide belt of western Turkey. Geological Magazine, v. 140(4), p. 421-441.

Reneau, S. L., 2000. Stream incision and terrace development in Frijoles Canyon, Bandelier National Monument, New Mexico, and the influence of lithology and climate. Geomorphology, v. 32(1), p. 171-193.

Roy, S. G., Tucker, G. E., Koons, P. O., Smith, S. M., and Upton, P., 2016. A Fault Runs through It: Modeling the Influence of Rock Strength and Grain-Size Distribution in a Fault-Damaged Landscape. Journal of Geophysical Research Earth Surface, v. 121 (10), p. 1911-30.

Scott, D. N., \& Wohl, E., 2019. Bedrock fracture influences on geomorphic process and form across process domains and scales. Earth Surf. Process. Landforms, v. 44: p. 27- 45. doi.org/10.1002/esp.4473.

Schwanghart, W. and Scherler, D, 2014. Short Communication: TopoToolbox 2 MATLAB-based software for topographic analysis and modeling in Earth surface sciences, Earth Surface Dynamics, v. 2, p. 1-7, https://doi.org/10.5194/esurf-2-12014.

Selby, M. J., 1980. A rock mass strength classification for geomorphic purposes: with tests from Antarctica and New Zealand. Zeitschrift für Geomorphologie, v. 24(1), p. 31-51.

Şensoy S, Demircan M, Ulupınar Y, Balta I. Climate of Turkey. 2008. Turkish State Meteorological Service, Ankara.

Seyitoğlu, G., and Scott, B. C., 1996. Age of the Alaşehir graben (west Turkey) and its tectonic implications. Geological Journal, v. 31(1), p. 1-11. 
Seyitoğlu, G., Tekeli, O., Çemen, I., Sen, S., and Isik, V., 2002. The role of the flexural rotation/rolling hinge model in the tectonic evolution of the Alasehir graben, western Turkey. Geological Magazine, v. 139(01), p. 15-26.

Sklar, L. S., and Dietrich, W. E., 2001. Sediment and rock strength controls on river incision into bedrock. Geology, v. 29(12), p. 1087-1090.

Snyder, N. P., Whipple, K. X., Tucker, G. E., Merritts, D. J., 2003. Channel response to tectonic forcing: field analysis of stream morphology and hydrology in the Mendocino triple junction region, northern California. Geomorphology, v. 53(1), p. 97-127.

Stock, J. D., and Montgomery, D. R., 1999. Geologic constraints on bedrock river incision using the stream power law. Journal of Geophysical Research, v. 104, p. 4983-4994.

Perron, J., and Fagherazzi, S., 2012. The legacy of initial conditions in landscape evolution. Earth Surface Processes and Landforms, v. 37(1), p. 52-63.

ten Veen, J. H., Boulton, S. J., and Alçiçek. M. C., 2009. From Palaeotectonics to Neotectonics in the Neotethys Realm: The Importance of Kinematic Decoupling and Inherited Structural Grain in SW Anatolia (Turkey). Tectonophysics v. 473, p. 261-81.

Tucker, G. E., and K. X. Whipple, 2002. Topographic outcomes predicted by stream erosion models: Sensitivity analysis and intermodel comparison, Journal of Geophysical Research, 10.1029/2001JB000162.

Tucker, G., Lancaster, S., Gasparini, N., and Bras, R., 2001. The channel-hillslope integrated landscape development model (CHILD). In: Landscape erosion and evolution modeling. Springer, Boston, MA. pp. 349-388.

Turowski, J.M., Lague, D. and Hovius, N., 2009. Response of bedrock channel width to tectonic forcing: Insights from a numerical model, theoretical considerations, and comparison with field data. Journal of Geophysical Research: Earth Surface, v. 114(F3).

Van Der Beek, P., and Bishop, P., 2003. Cenozoic river profile development in the Upper Lachlan catchment (SE Australia) as a test of quantitative fluvial incision models. Journal of Geophysical Research: Solid Earth, v. 108(B6).

Van De Wiel, M. J., Coulthard, T. J., Macklin, M. G., and Lewin, J., 2007. Embedding reach-scale fluvial dynamics within the CAESAR cellular automaton landscape evolution model. Geomorphology, v. 90(3), p. 283-301.

Whipple, K. X., 2004. Bedrock rivers and the geomorphology of active orogens. Annual Review of Earth and Planetary Sciences, v. 32, p. 151-185.

Whipple, K. X., and Tucker, G. E., 1999. Dynamics of the stream- power river incision model: Implications for height limits of mountain ranges, landscape response timescales, and research needs. Journal of Geophysical Research: Solid Earth, v. 104(B8), p. 17661-17674. 
Whipple, K. X., and Tucker, G. E., 2002. Implications of sediment- flux- dependent river incision models for landscape evolution. Journal of Geophysical Research: Solid Earth, v. 107(B2), ETG-3.

Whipple, K. X., Hancock, G. S., and Anderson, R. S., 2000. River incision into bedrock: Mechanics and relative efficacy of plucking, abrasion, and cavitation. Geological Society of America Bulletin, v. 112(3), p. 490-503.

Whittaker, A.C., Cowie P.A., Attal, M., Tucker G.E. and Roberts, G., 2007, Bedrock channel adjustment to tectonic forcing: Implications for predicting river incision rates, Geology, 35, 103-106Whittaker, A.C., 2012, How do landscapes record tectonics and climate? Lithosphere, 4, 160-164

Whittaker, A. C. and Boulton, S. J., 2012. Tectonic and climatic controls on knickpoint retreat rates and landscape response times. Journal of Geophysical Research, v. 117.

Whittaker, A. C., Cowie, P. A., Attal, M., Tucker, G.E., Roberts, G.P., 2007a. Bedrock channel adjustments to tectonic forcing: Implications for predicting river incision rates. Geology, v. 35 (2), p. 103-106.

Whittaker, A. C., Cowie, P. A., Attal, M., Tucker, G. E., and Roberts, G. P., 2007b. Contrasting transient and steady-state rivers crossing active normal faults: New field observations from the Central Apennines, Italy. Basin Research, v. 19(4), p. 529-556.

Whittaker, A. C., Cowie, P.A., Attal, M., Tucker, G.E., Roberts, G.P., 2008. Decoding temporal and spatial patterns of fault uplift using transient river long profiles. Geomorphology, v. 100, p. 506-526.

Willgoose, G., 2005. Mathematical modelling of whole landscape evolution. Annual Review of Earth and Planetary Sciences, v. 33, p. 443-459.

Wobus, C., Whipple, K.X., Kirby, E., Snyder, N.P., Johnson, J., Spyropolou, K., Crosby, B.T., and Sheehan, D., 2006. Tectonics from topography: Procedures, promise, and pitfalls, in, Willett, S.D., Hovius, N., Brandon, M.T., and Fisher, D.M., eds., Tectonics, Climate, and Landscape Evolution: Geological Society of America Special Paper 398, p. 55-74, doi: 10.1130/2006.2398(04).

Wong, M., and Parker, G., 2006. Reanalysis and correction of bed-load relation of Meyer-Peter and Müller using their own database. Journal of Hydraulic Engineering, v. 132(11), p. 1159-1168.

Yanites, B. J., Becker, J. K., Madritsch, H., Schnellmann, M., and Ehlers, T. A., 2017. Lithologic effects on landscape response to base level changes: a modeling study in the context of the Eastern Jura Mountains, Switzerland. Journal of Geophysical Research: Earth Surface, v. 122(11), p. 2196-2222.

Zondervan, J.R., Whittaker, A.C., Bell, R.E., Watkins, S.E., Brooke, S.A.S., and Hann, M.G., 2020a. New constraints on bedrock erodibility and landscape 
response times upstream of an active fault, Geomorphology, v. 351, p. 106937106937

Zondervan, J.R., Stokes, M., Boulton, S.J., Telfer, M.W., and Mather A.E., 2020b. Rock strength and structural controls on fluvial erodibility: Implications for drainage divide mobility in a collisional mountain belt. Earth and Planetary Science Letters, v. 538, p. 116221-116221

\section{FIGURE CAPTIONS}

Figure 1. A) Map of the Aegean region showing major plate boundaries and the location of the area of the Western Anatolian Extensional Province (WAEP) shown in B; B) Shaded topographic map of the central part of the Eastern Anatolian Extensional Province overlain with major active normal fault systems and associated grabens (BMG - Büyük Menderes Graben; KMG - Kücük Menderes Graben; GZG Gediz Graben; DG - Demirci Graben; GG- Gördes Graben). Topographic profiles shown to the right cross the Bözdağ block, a horst located between the GZG and KMG; the location of the profiles are indicated on the map. C) SRTM 30m DEM overlain with simplified lithology, major faults, catchments of studied rivers and slip rates at the range front where those rivers discharge (map modified and data from Kent et al., 2017).

Figure 2. Photographs illustrating key features of the fluvial geomorphology. A) Incised metamorphic bedrock reach on the Akçapınar River; B) wide fluvial plain near the basin bounding fault on the Yeniköy River; C) View of uplifted and eroding Cenozoic sedimentary units typical of the incised landscape downstream of the knickpoints; D) View of the upper reaches of the Akçapınar river showing $\sim 300 \mathrm{~m}$ of incision into a low relief pre-incision landscape.

Figure 3. River long profiles showing main lithological groups found in the footwall of the active fault, the location of the range front fault and the tectonic knickpoint (star) for the A) Akçapınar, B) Sartçay, C) Bözdağ D) Kabazlı, E) Yeniköy and F) Badınca Rivers

Figure 4. Violin plots showing the variation in Schmidt hammer and SRMS data for the three main lithological groups. Note: the violin plot shows the probability density of data at each value, and incorporates a box and whisker plot; where the box indicates the upper/lower quartiles, the vertical lines the data range and the horizontal line the data median. Solid circles indicate outliers in the data. The median for the Schmidt hammer data for the sediments overlaps with the lower quartile. 
1152 Figure 5. Downstream variation in SRMS and Schimdt hammer rebound strength for 1153 each river, with the bedrock type, fault and knickpoint location shown in the bar 1154 above for the A) Akçapınar, B) Sartçay, C) Bözdağ D) Kabazlı, E) Yeniköy and F) 1155 Badınca Rivers.

Figure 6. Downstream variation in unit stream power measured at each field site (small squares) and reach-averaged stream power (circles) for the $\underline{A}$ ) Akçapınar, B) 1159 Sartçay, C) Bözdağ D) Kabazlı, E) Yeniköy and F) Badınca Rivers. As in previous graphs the location of the fault is shown, as well as the knickpoint, knickzone and the extent of metamorphic and sedimentary bedrock.

Figure 7. A) Graph of unit stream power against Schmidt hammer rebound strength and SRMS for different lithologies and river reaches. Note the overall trend of increasing stream power with higher strength indices. B) Calculated bedrock erodibility $k_{b}$, for the sedimentary lithologies (white circles) and metamorphic rocks (black circles); note that the two populations of data fall in distinct groups differing by an order of magnitude.

Figure 8. A) Graph of maximum reach-averaged stream power in the metamorphic basement rocks against fault throw rates where the rivers enter the Gediz Graben (taken from Kent et al. (2017)). Note that the Yeniköy (in white) is an outlier to the clear trend of increasing stream power with higher throw rates. B) Reach-averaged stream power in the sedimentary units within $2 \mathrm{~km}$ of the fault of the fault. The Akçapınar river is not shown as it only incises gneisses and schists.

Figure 9. Meyer Peter Muller (MPM) bedload transport capacity against fault throw rate, averaged for the sedimentary units $2 \mathrm{~km}$ upstream of the fault. Greater fault throw rate is associated with higher maximum transport capacities. Error bars together represent one standard deviation in values across all measuring sites within the reach for which the transport capacity is calculated. 


\begin{tabular}{|c|c|c|c|c|c|c|}
\hline & Akçapınar & Sart & Bozdag & Kabazli & Yanikoy & Badica \\
\hline Throw rate at fault ${ }^{1}(\mathrm{~mm} / \mathrm{yr})$ & 1.41 & 1.84 & 2 & 1.74 & 1.3 & 0.72 \\
\hline Catchment drainage area, $\mathrm{A}$, at fault $\left(\mathrm{km}^{2}\right)$ & 46.7 & 73.2 & 70.8 & 26.5 & 14.5 & 28.8 \\
\hline \multicolumn{7}{|l|}{ Max reached-averaged stream power, $\omega$, } \\
\hline $\mathrm{W} / \mathrm{m}^{2}$ & 1372 & 1657 & 2895 & 1435 & 653 & 962 \\
\hline Max streampower \pm error $(1 / 2 \sigma)$ & 216 & 325 & 763 & 587 & 243 & 34 \\
\hline $\begin{array}{l}\text { Averaged stream power } \sim 2 \mathrm{~km} \text { upstream of } \\
\text { fault } \mathrm{W} / \mathrm{m}^{2}\end{array}$ & 788 & 327 & 130 & 154 & 28 & 190 \\
\hline Averaged streampower \pm error $(1 / 2 \sigma)$ & 309 & 114 & 67 & 43 & 2 & 34 \\
\hline $\begin{array}{l}\text { Schmidt hammer rebound average } 2 \mathrm{~km} \text { from } \\
\text { fault }\end{array}$ & 38.9 & 20.0 & 27.8 & 23.3 & 19.7 & 21.7 \\
\hline Schmidt \pm error $(\sigma)$ & 11.3 & 0.0 & 13.0 & 2.8 & 0.6 & 3.0 \\
\hline Selby RMS $2 \mathrm{~km}$ from fault & 59.1 & 52.0 & 60.5 & 44.7 & 51.3 & 52.0 \\
\hline Selby \pm error $(\sigma)$ & 6.6 & 0.0 & 7.3 & 2.1 & 6.9 & 0.0 \\
\hline $\begin{array}{l}\text { Schmidt hammer rebound average for max } \\
\text { stream power reach }\end{array}$ & 49.9 & 60.9 & 45.6 & 35.7 & 54.0 & 45.9 \\
\hline Schmidt \pm error $(\sigma)$ & 12.5 & 3.3 & 7.1 & 13.8 & 6.2 & 7.1 \\
\hline $\begin{array}{l}\text { Selby RMS average for max stream power } \\
\text { reach }\end{array}$ & 67.0 & 63.1 & 65.2 & 56.0 & 66.5 & 66.5 \\
\hline Selby RMS \pm error $(\sigma)$ & 8.7 & 3.2 & 4.2 & 10.8 & 14.8 & 6.8 \\
\hline Calculated $k_{b}$ metamorphics $\left(\mathrm{m} \mathrm{s}^{2} \mathrm{~kg}^{-1}\right)$ & $3.26 \mathrm{E}-14$ & $3.52 E-14$ & 2.19E-14 & $3.84 \mathrm{E}-14$ & $6.31 \mathrm{E}-14$ & 2.37E-14 \\
\hline Min $k_{b}$ metamorphics $\left(\mathrm{m} \mathrm{s}^{2} \mathrm{~kg}^{-1}\right)$ & $2.82 \mathrm{E}-14$ & 2.94E-14 & $1.73 \mathrm{E}-14$ & 2.73E-14 & 4.60E-14 & 2.29E-14 \\
\hline $\operatorname{Max} k_{b}$ metamorphics $\left(\mathrm{m} \mathrm{s}^{2} \mathrm{~kg}^{-1}\right)$ & 3.ర/t-14 & 4.3రt-14 & L.y/t-14 & 0.つ」t-14 & 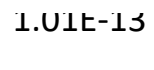 & L.40t-14 \\
\hline $\begin{array}{c}\text { Calculated } k_{b} \text { sedimentary lithologies (m } \\
\qquad \mathrm{s}^{2} \mathrm{~kg}^{-1} \text { ) }\end{array}$ & & $1.78 \mathrm{E}-13$ & $4.88 \mathrm{E}-13$ & 3.59E-13 & 1.49E-12 & $1.20 \mathrm{E}-13$ \\
\hline Min $k_{b}$ sedimentary lithologies $\left(\mathrm{m} \mathrm{s}^{2} \mathrm{~kg}^{-1}\right)$ & & $1.32 \mathrm{E}-13$ & $3.22 \mathrm{E}-13$ & $2.81 \mathrm{E}-13$ & $1.38 \mathrm{E}-12$ & $1.02 \mathrm{E}-13$ \\
\hline Max $k_{b}$ sedimentary lithologies $\left(\mathrm{m} \mathrm{s}^{2} \mathrm{~kg}^{-1}\right)$ & & 2.73E-13 & $1.01 \mathrm{E}-12$ & 4.97E-13 & 1.61E-12 & $1.46 \mathrm{E}-13$ \\
\hline $\begin{array}{l}\text { MPM transport capacity average } \sim 2 \mathrm{~km} \text { from } \\
\text { fault }\left(\mathrm{kgs}^{-1}\right)\end{array}$ & & 168 & 333 & 172.6 & 120 & 111.7 \\
\hline MPM \pm error $(1 / 2 \sigma)$ & & 70.8 & 83 & 16.5 & 12 & 17 \\
\hline
\end{tabular}

${ }^{1}$ estimated uncertainty on throw rate at fault is $\pm 0.2 \mathrm{~mm} / \mathrm{y}$ 

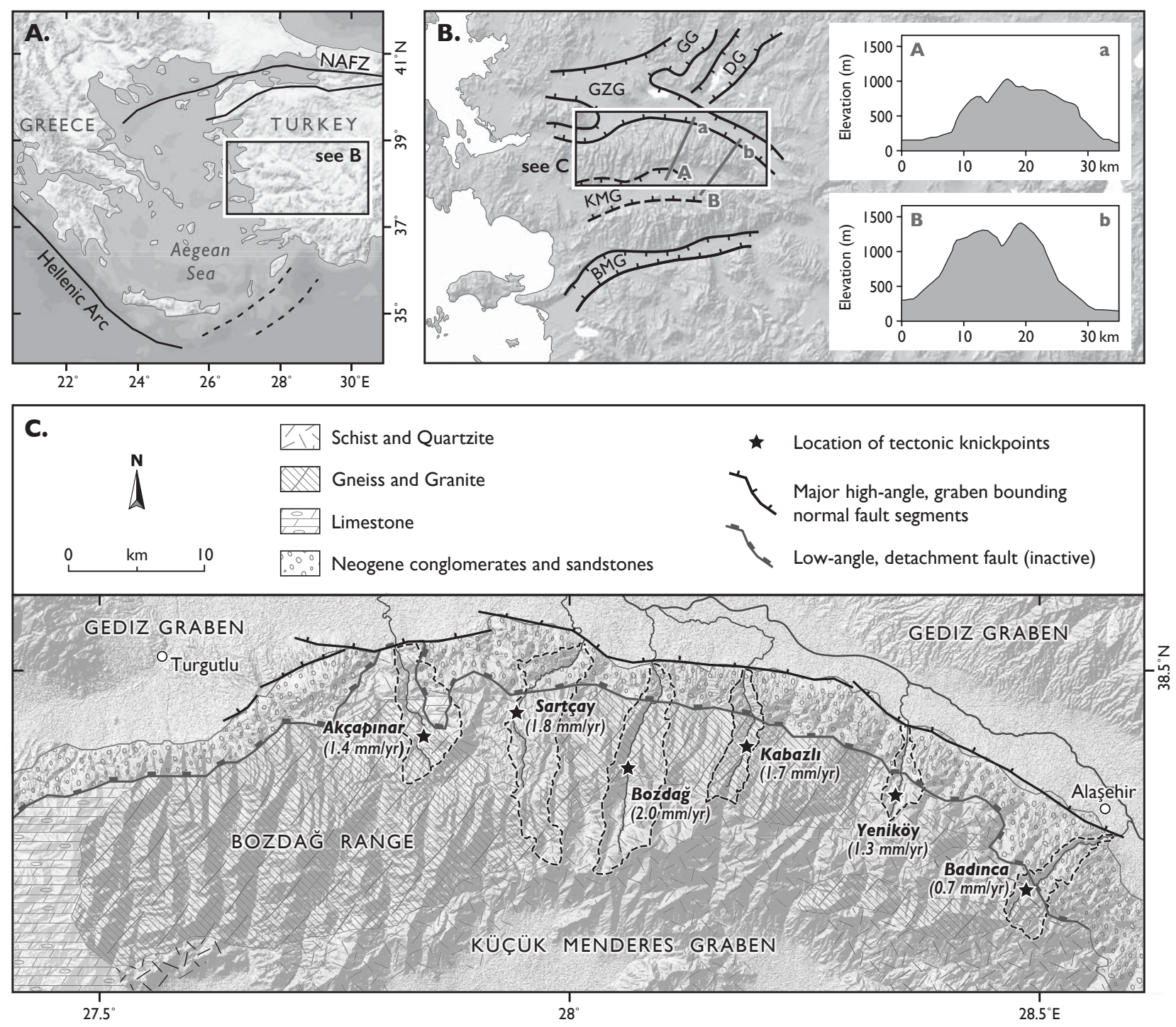


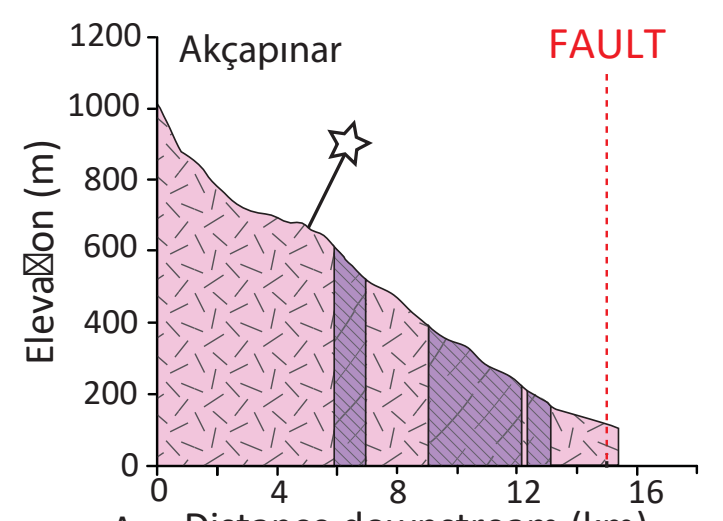

A. Distance downstream $(\mathrm{km})$
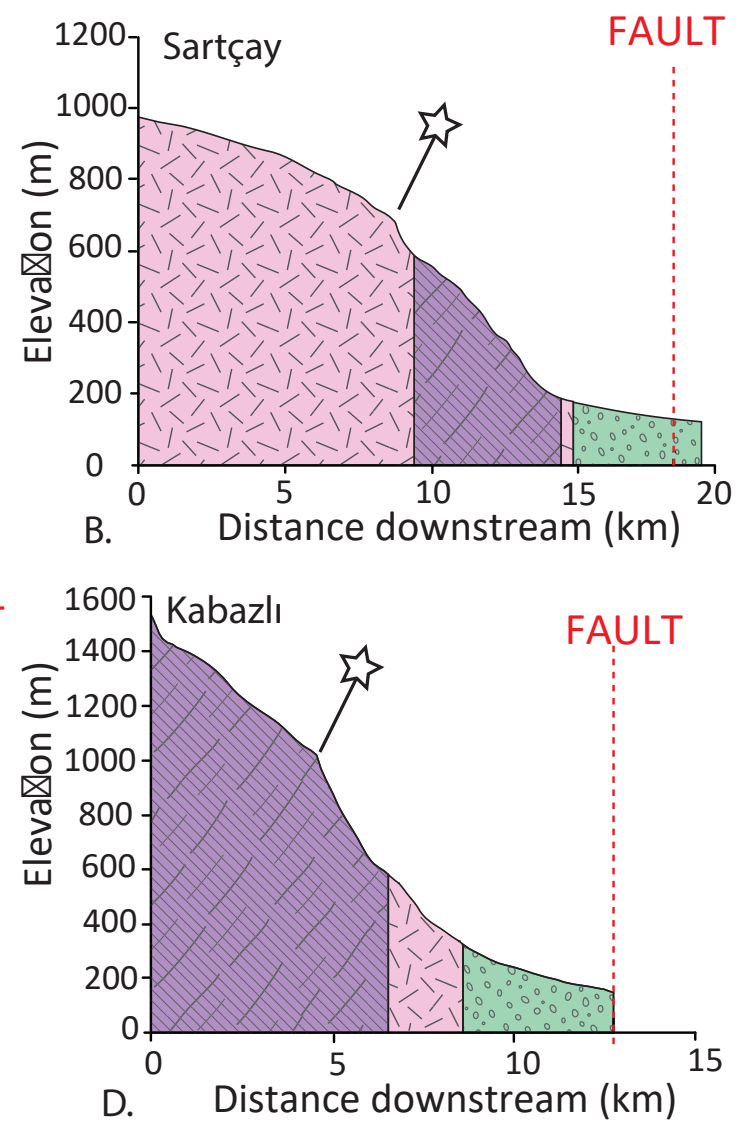

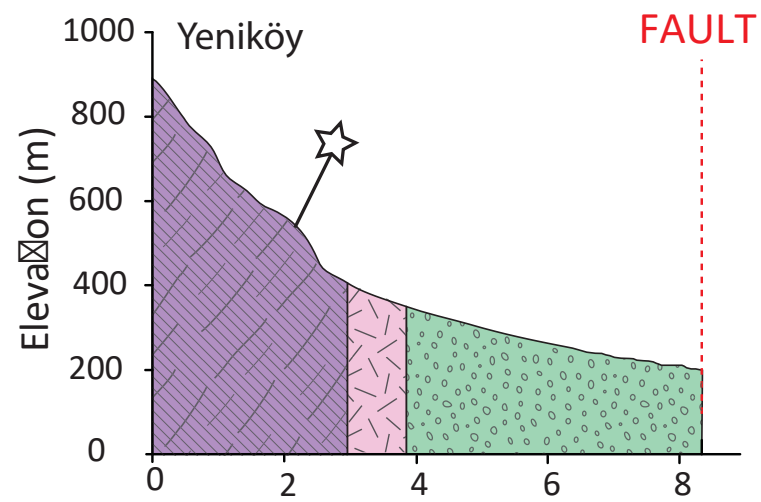

E. Distance downstream $(\mathrm{km})$

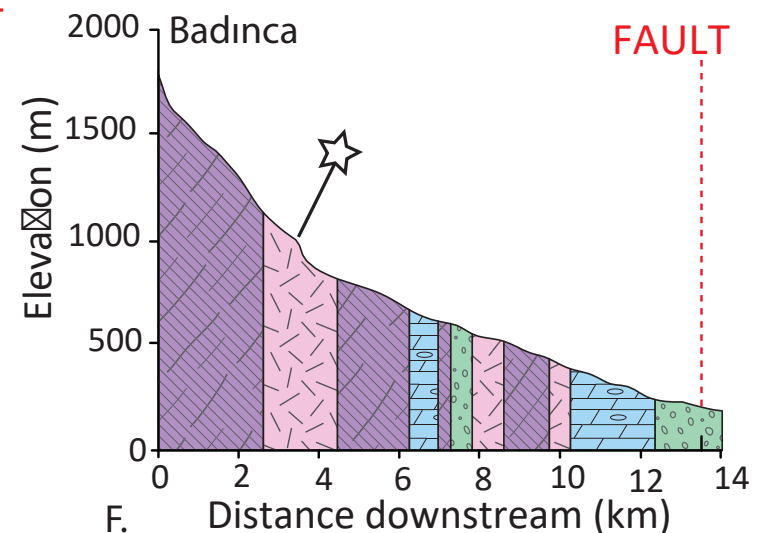

Clas》c sediments [-T Schist

Gneiss \& Granite

Traver冈ne 


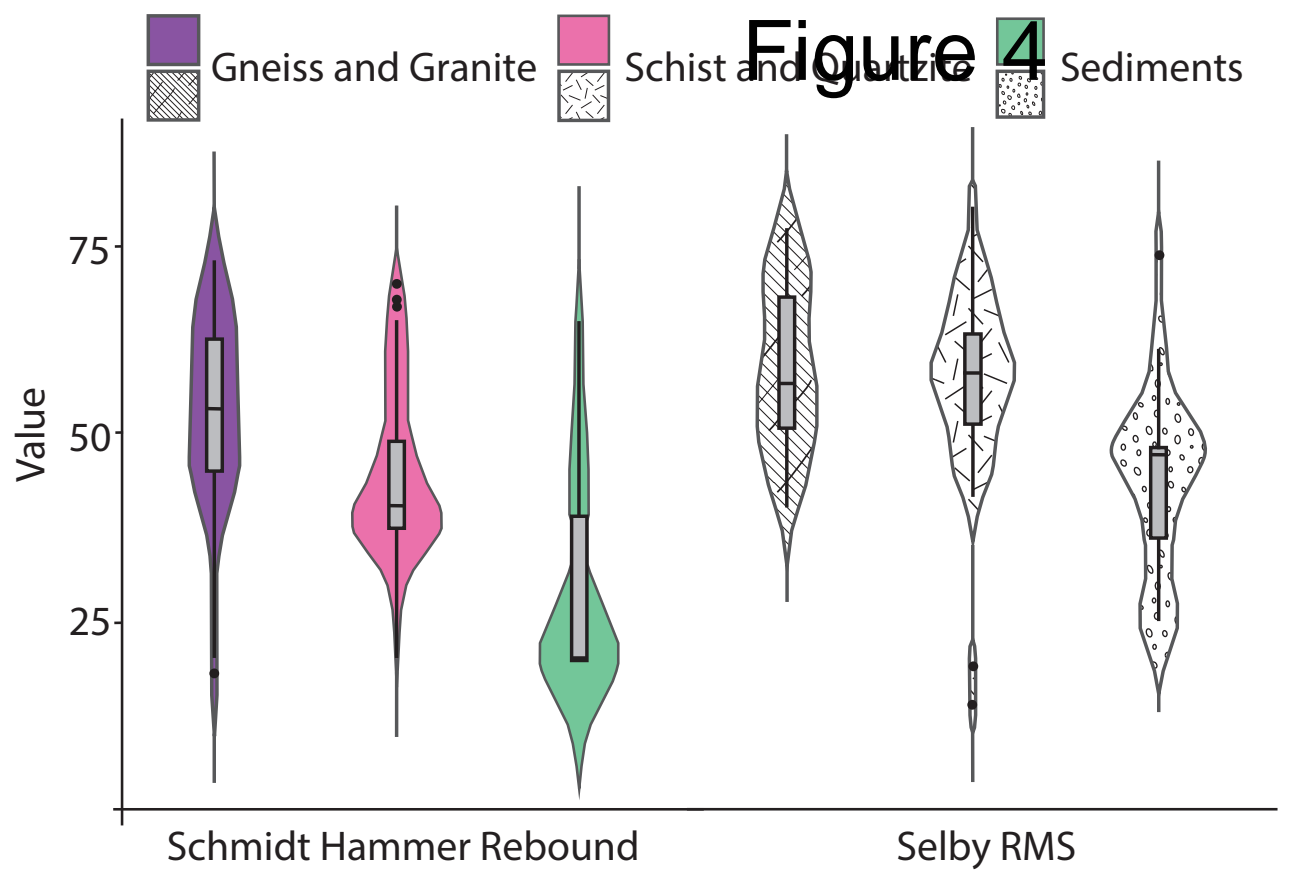




\section{$\square$ Schmidt rebound hardness $\quad$ S Selby RMS index reach-averaged SRMS

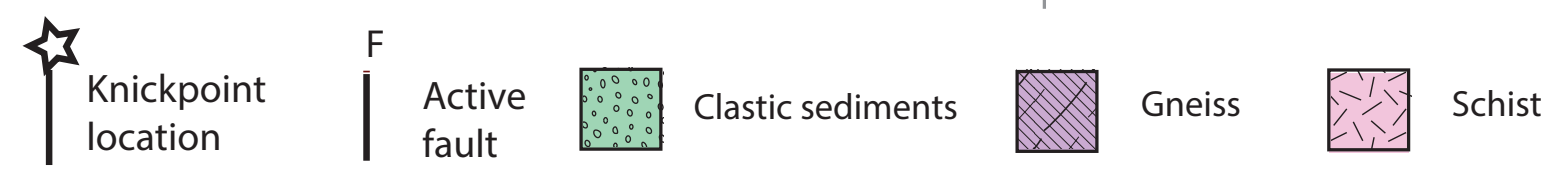
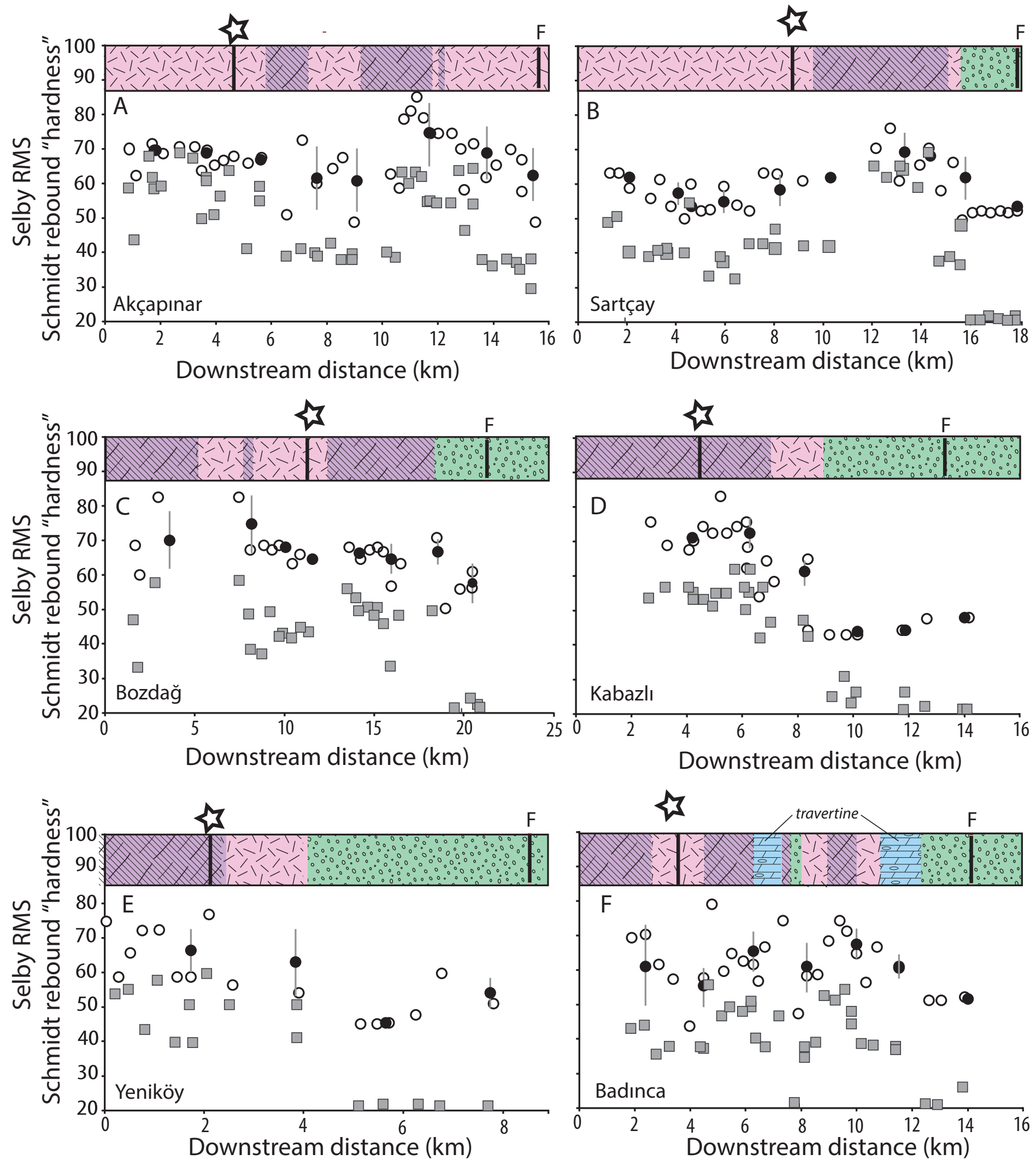

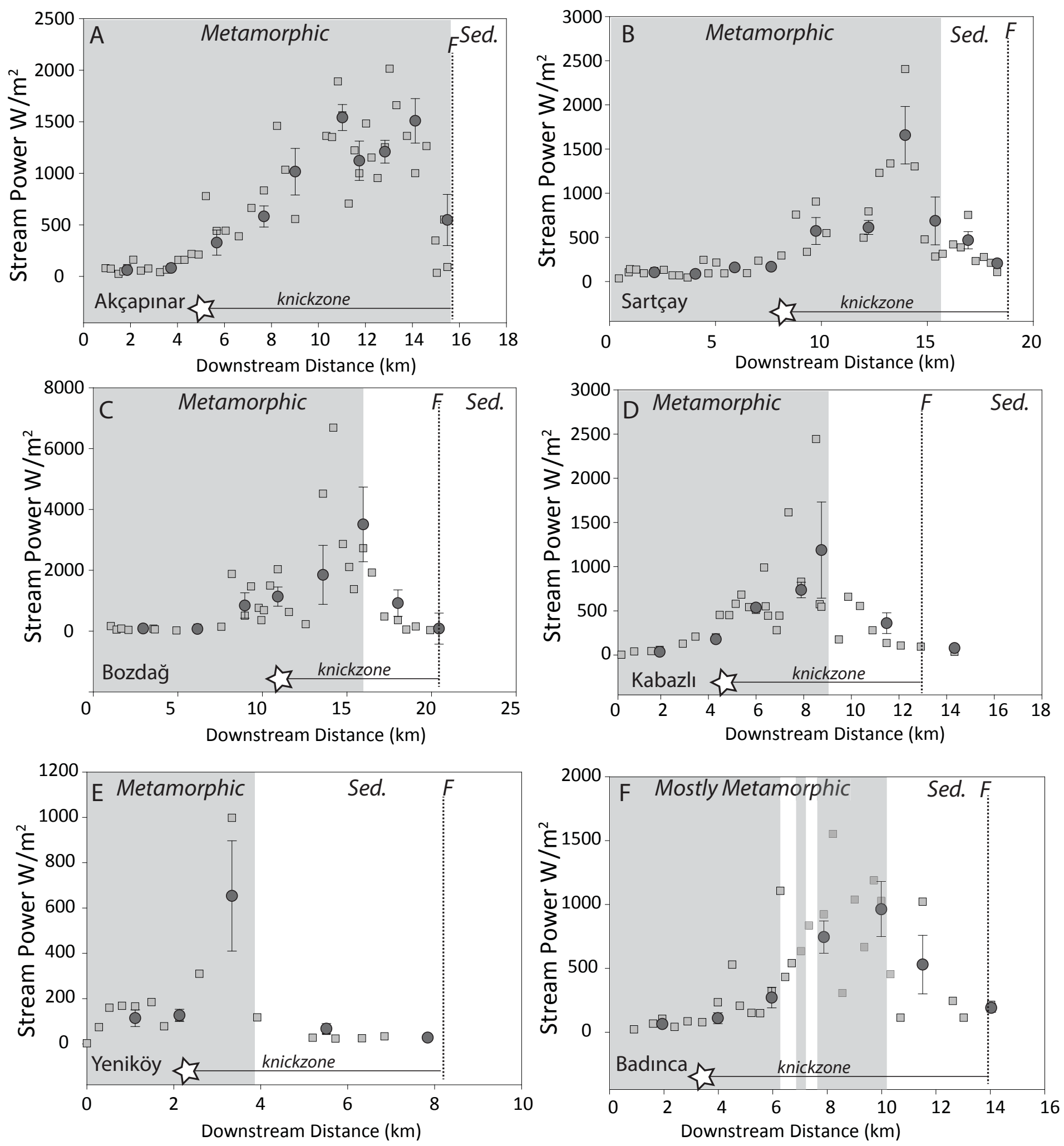

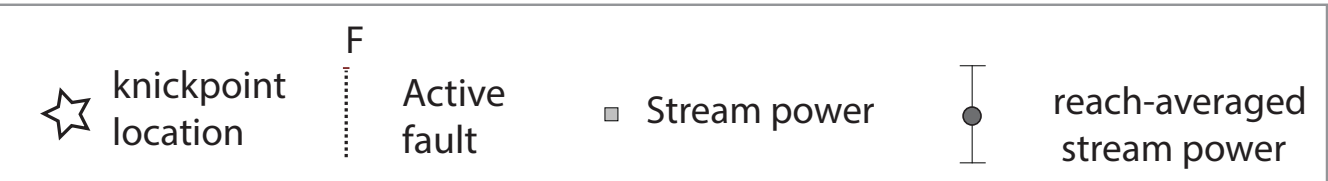



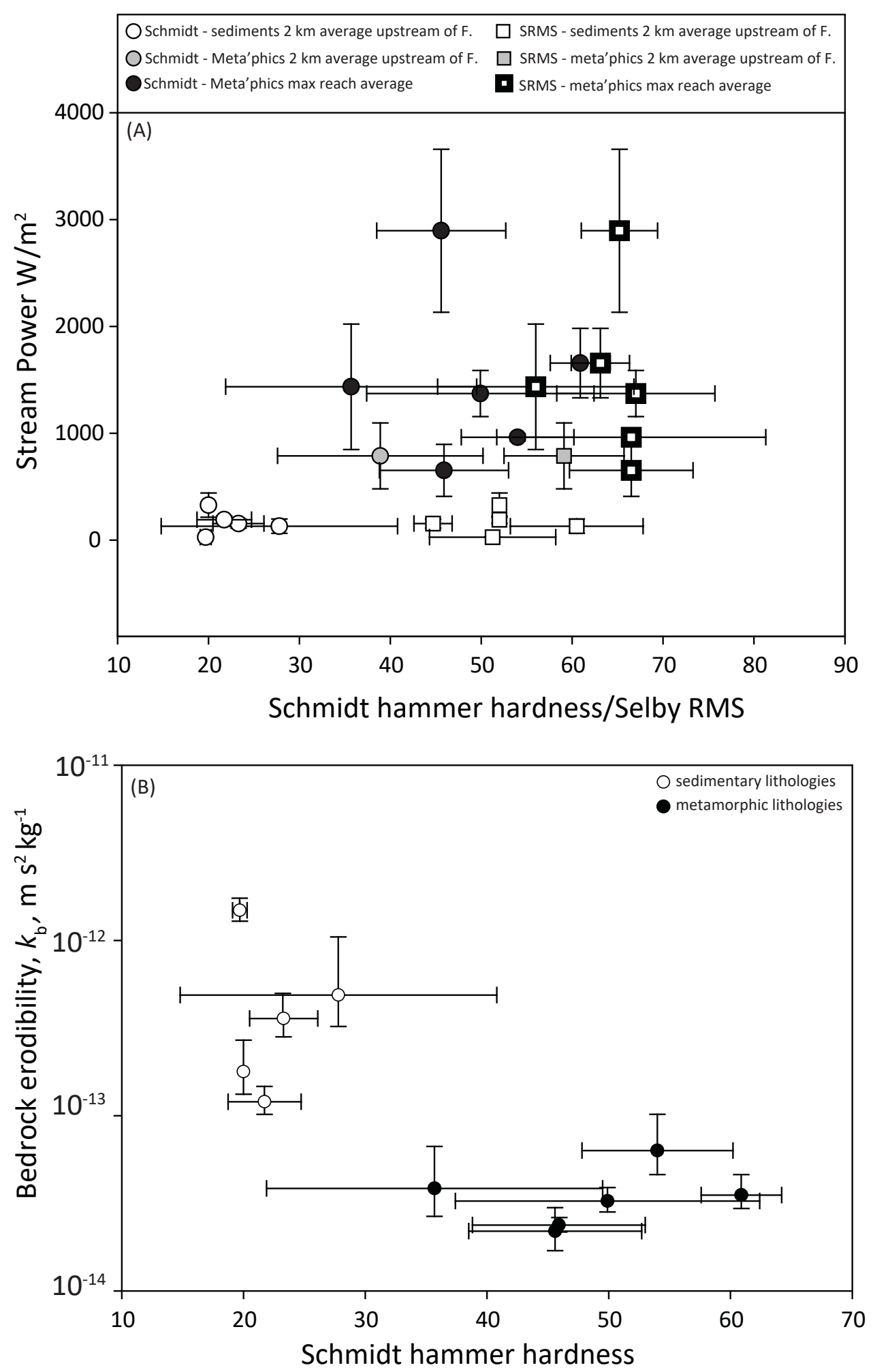

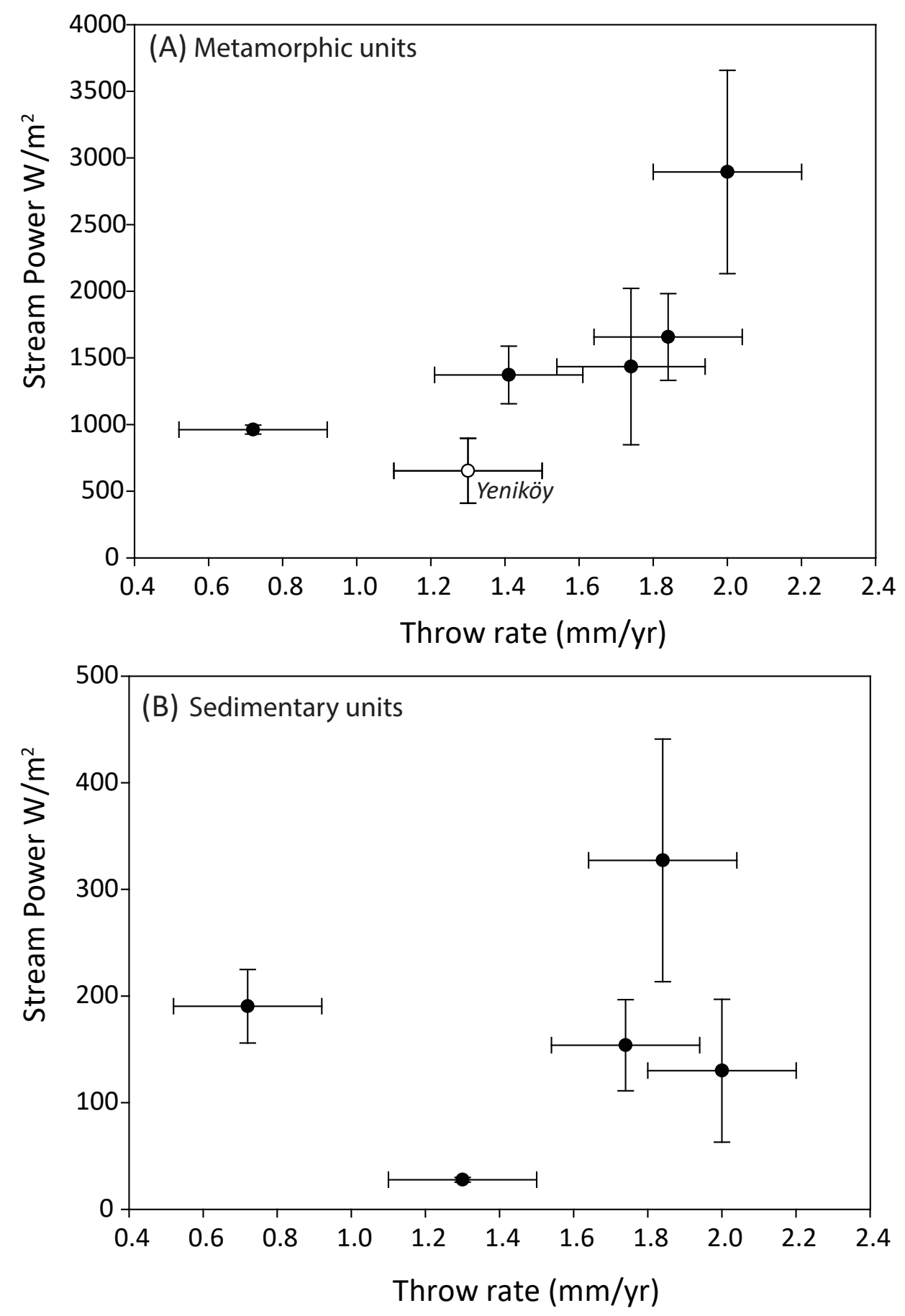
Figure 9

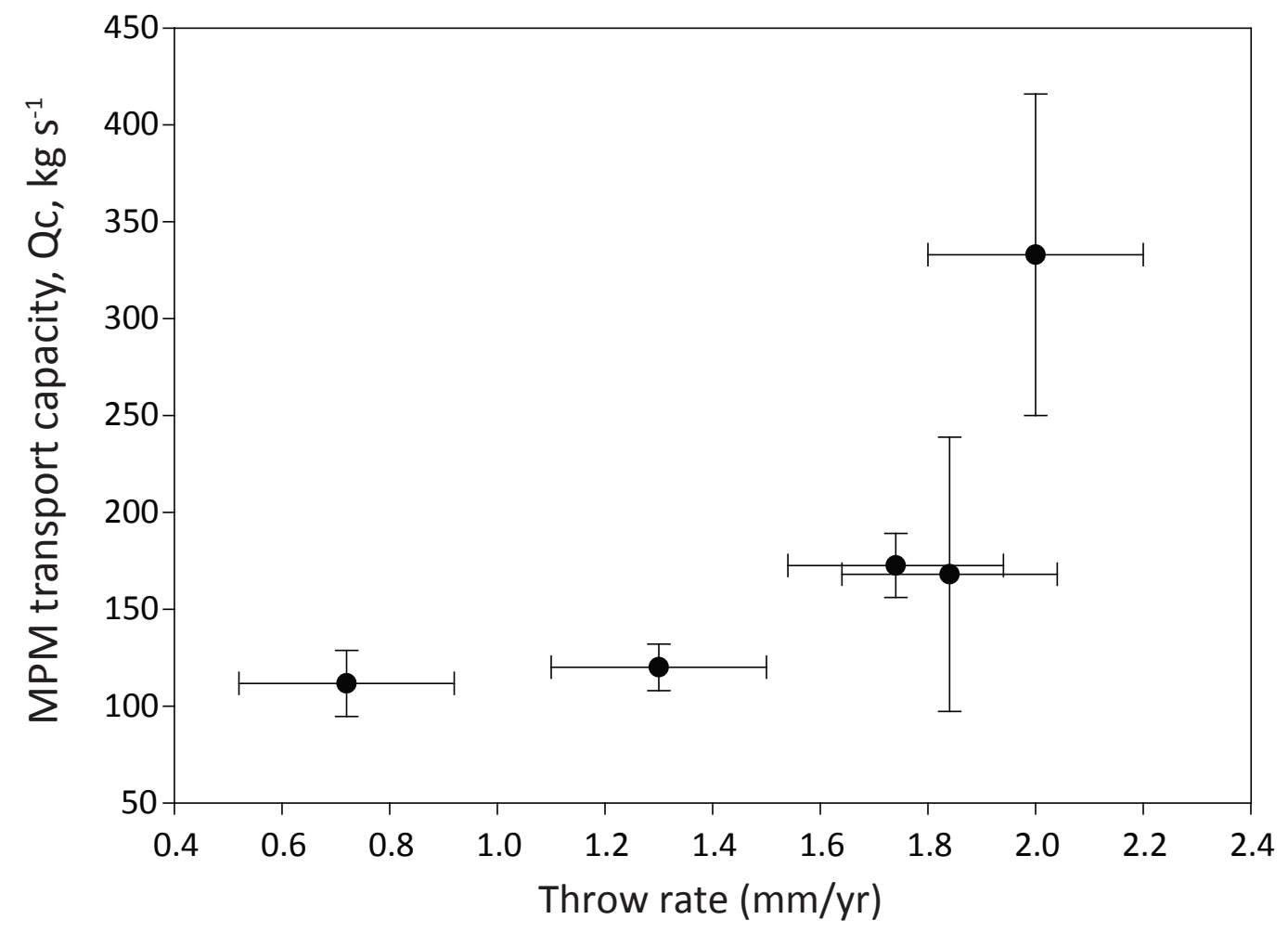

